\title{
Lesions of the Medial Geniculate Nuclei Specifically Block Corticosterone Release and Induction of c-fos mRNA in the Forebrain Associated with Audiogenic Stress in Rats
}

\author{
Serge Campeau, Huda Akil, and Stanley J. Watson \\ Mental Health Research Institute, The University of Michigan, Ann Arbor, Michigan 48109
}

\begin{abstract}
Audiogenic stress is known to activate the hypothalamopituitary-adrenocortical (HPA) axis in rats. The goal of the present study was to determine whether the medial geniculate nuclei (including all auditory nuclei of the thalamus), which are obligatory relays in the transmission of auditory information to the forebrain, are critically involved in HPA activation by audiogenic stress. To this end, corticosterone levels and regional brain activity indexed by c-fos mRNA induction, elicited by 30 min of $105 \mathrm{~dB}$ white noise, were measured. Compared with unoperated and sham-operated rats, complete medial geniculate nuclei lesions blocked corticosterone release normally induced by loud noise. The effects of the lesions were specific to loud noise insofar as corticosterone release in response to restraint or ether stress was not reduced in lesioned rats.

We have determined previously that audiogenic stress is associated with a specific regional pattern of c-fos mRNA induction. Rats sustaining complete medial geniculate lesions demonstrated a blockade of c-fos mRNA induction in several audiogenic stress responsive regions, also known to directly innervate medial parvocellular neurons of the paraventricular
\end{abstract}

hypothalamic nucleus. Thus, in addition to blockade in the paraventricular hypothalamic nucleus, c-fos mRNA induction in the lesioned animals was abolished in the bed nucleus of the stria terminalis, especially its anterior medial and ventral aspects, the septohypothalamic nucleus, and the anteroventral preoptic area, compared with unoperated and sham-operated rats. Several additional regions in the lesioned rats failed to show reliable c-fos $\mathrm{mRNA}$ induction compared with naive rat controls. Nearly all other regions that showed reliable c-fos mRNA induction in the unoperated and sham-operated rats displayed either similar or slightly reduced levels in complete medial geniculate-lesioned rats, suggesting that these regions are not part of a critical HPA activational circuit in response to audiogenic stress. On the basis of these results, putative circuits from the medial geniculate nuclei to the paraventricular nucleus of the hypothalamus involved in activation of the HPA axis by audiogenic stress are discussed.

Key words: corticosterone; loud noise; auditory; restraint; ether; rat
The CNS plays an essential role in the regulation of glucocorticoid secretion in response to stressful events. Most of the evidence indicates that the release of glucocorticoids by stress is mediated through the hypothalamo-pituitary-adrenocortical (HPA) axis (for reviews, see Whitnall, 1993; Akil and Morano, 1996; Herman et al., 1996). Corticotropin-releasing hormone $(\mathrm{CRH})$ containing neurons of the medial parvocellular paraventricular nucleus (mpPVN) of the hypothalamus are at the origin of the HPA axis (Antoni, 1986; Swanson et al., 1988). These mpPVN hypothalamic neurons have been proposed to provide the initial common node activated by several types of stressful events (Sawchenko, 1991). Although the afferent innervation of mpPVN neurons is relatively well documented (Sawchenko and Swanson, 1982, 1983; Cunningham et al., 1990; Cullinan et al., 1996; Herman et al., 1996), it is not yet clear which of these inputs are critical for activation of mpPVN neurons in response to most stressors. In one of the best characterized systems, HPA activation via immune challenge is mediated by medullary cat-

Received March 17, 1997; revised May 14, 1997; accepted May 15, 1997.

This research was supported by National Institute of Mental Health Grant MH-42251 (S.J.W.) and a Postdoctoral Fellowship from the Medical Research Council of Canada (S.C). Thanks are extended to Dr. Heidi E. W. Day for critical comments on an earlier draft of this manuscript.

Correspondence should be addressed to Serge Campeau, Mental Health Research Institute, The University of Michigan, 205 Zina Pitcher Place, Ann Arbor, MI 48109-0720.

Copyright (C) 1997 Society for Neuroscience $\quad 0270-6474 / 97 / 175979-14 \$ 05.00 / 0$ echolaminergic neurons, which directly innervate mpPVN neurons (Li et al., 1996; Sawchenko et al., 1996). The precise pathways through which most other stressors activate mpPVN neurons remain largely speculative (Herman et al., 1996; Herman and Cullinan, 1997).

To help delineate the functional circuits involved in mpPVN activation, several studies using immediate-early genes (e.g., c-fos, c-jun, zif/268) have mapped the neural circuits mediating HPA activation to various stressors (Campeau et al., 1991; Schreiber et al., 1991; Sharp et al., 1991; Arnold et al., 1992; Pezzone et al., 1992, 1993; Smith et al., 1992; Duncan et al., 1993; Senba et al., 1993; Bonaz and Tache, 1994; Melia et al., 1994; Beck and Fibiger, 1995; Cullinan et al., 1995, 1996; Day and Akil, 1996; Duncan et al., 1996; Li et al., 1996). The few detailed and quantitative analyses of immediate-early gene expression have revealed that different stressors (restraint/immobilization, forced swim, and fear) activate a large number of brain areas (Beck and Fibiger, 1995; Duncan et al., 1996); however, the complex characteristics of the stressful stimuli and the inability to control for processes other than stress in these studies render the assignment of a stress-specific role for any Fos positive region difficult.

Recently, we found that auditory stimulation produces distinct patterns of c-fos mRNA induction in rat brain based on the intensity of the acoustic stimulus (Campeau and Watson, 1997). First, after exposure to the experimental cages, rats displayed an auditory intensity-independent wide pattern of brain c-fos mRNA 
induction, including several cortical, thalamic, and brainstem structures, presumably reflecting exploratory behavior. Second, a number of auditory structures (cochlear nuclei, superior olivary complex, nuclei of the lateral lemniscus, inferior colliculus, and the medial division of the medial geniculate body/posterior intralaminar nucleus) showed a clear intensity-dependent increase in c-fos mRNA induction. Third, exposure of rats to the highest noise intensities ( 90 and $105 \mathrm{~dB}$, A scale), which were stressful as indicated by significant corticosterone release, produced higher c-fos mRNA induction in some areas contained mostly in the forebrain, compared with rats exposed to lower, nonstressful noise intensities. Some of these audiogenic stress-responsive forebrain structures have direct projections to mpPVN neurons.

The main goals of the present study were to determine whether auditory signals induced by loud noise need to reach the forebrain to activate the HPA axis and how the previously determined regional pattern of c-fos mRNA induction would be altered by removing direct auditory inputs to the forebrain. Centrally, auditory signals are processed and relayed by a number of brainstem nuclei (cochlear nuclei, superior olivary complex, nuclei of the lateral lemniscus) to the inferior colliculus (Aitkin, 1990; Helfert et al., 1991). In turn, the inferior colliculus relays auditory information to several nuclei of the thalamus (all subdivisions of the medial geniculate body, and the surrounding suprageniculate and intralaminar nuclei), which will collectively be called the medial geniculate nuclei here and which provide obligatory relays for auditory information to reach the auditory cortex and other forebrain areas (LeDoux et al., 1985, 1987, 1990). Thus, the necessity of forebrain auditory inputs in audiogenic stressinduced HPA activation was tested by disrupting all the medial geniculate nuclei. The effects of fiber-sparing excitotoxic lesions with ibotenic acid injections in the medial geniculate nuclei were assessed by quantifying c-fos mRNA induction regionally using in situ hybridization histochemistry and by measuring corticosterone secretion, which is significantly elevated in response to audiogenic stress (Henkin and Knigge, 1963; Collu and Jequier, 1976; Borrell et al., 1980; Armario et al., 1984; Irwin et al., 1989; Segal et al., 1989; Britton et al., 1992; Campeau and Watson, 1997). The results indicated that the medial geniculate body is part of a circuit necessary for the release of corticosterone specifically in response to loud noise but not to restraint or ether stress.

\section{MATERIALS AND METHODS}

Subjects. Naive male albino Sprague Dawley rats $(n=48)$ weighing 250-300 gm on arrival from Charles River Company (Kingston, NY) were used as experimental animals. They were housed in groups of two in plastic cages $(20 \times 25 \times 50 \mathrm{~cm})$. The animal colony was maintained on a $12 \mathrm{hr}$ light/dark cycle (lights on at 7:00 A.M.). Rats were acclimated to the colony room for 1 week before the experiments began. Water and laboratory chow were freely available. The ambient noise level in the animal colony was $\sim 50 \mathrm{~dB}$ (A scale). All procedures were performed between 7:00 A.M. and 1:00 P.M.

Apparatus. The experimental boxes were two identical $20 \times 25 \times 30$ $\mathrm{cm}$ Plexiglas cages with the floor made of stainless steel rods $(2 \mathrm{~mm}$ bars spaced $1.2 \mathrm{~cm}$ apart, center to center). The cages were enclosed in a ventilated, dimly lit ( $20 \mathrm{~W}$ incandescent bulb), sound-attenuating LeHigh Valley chamber $(53 \times 56 \times 96 \mathrm{~cm})$. A Grass AM7 Audio Monitor speaker, placed between and adjacent to the two experimental cages, was used to deliver white noise $(0-20 \mathrm{kHz})$. The noise source was a General Radio Random-Noise Generator (Type 1390-A). The intensity of the noise was measured by placing a Radio Shack Realistic Sound Level Meter (No. 33-2050; A scale) in the closed cages. Ambient noise in the LeHigh Valley acoustic enclosure was $\sim 55 \mathrm{~dB}$ (A scale). This will be referred to hereafter as the background noise level of the experimental cages.

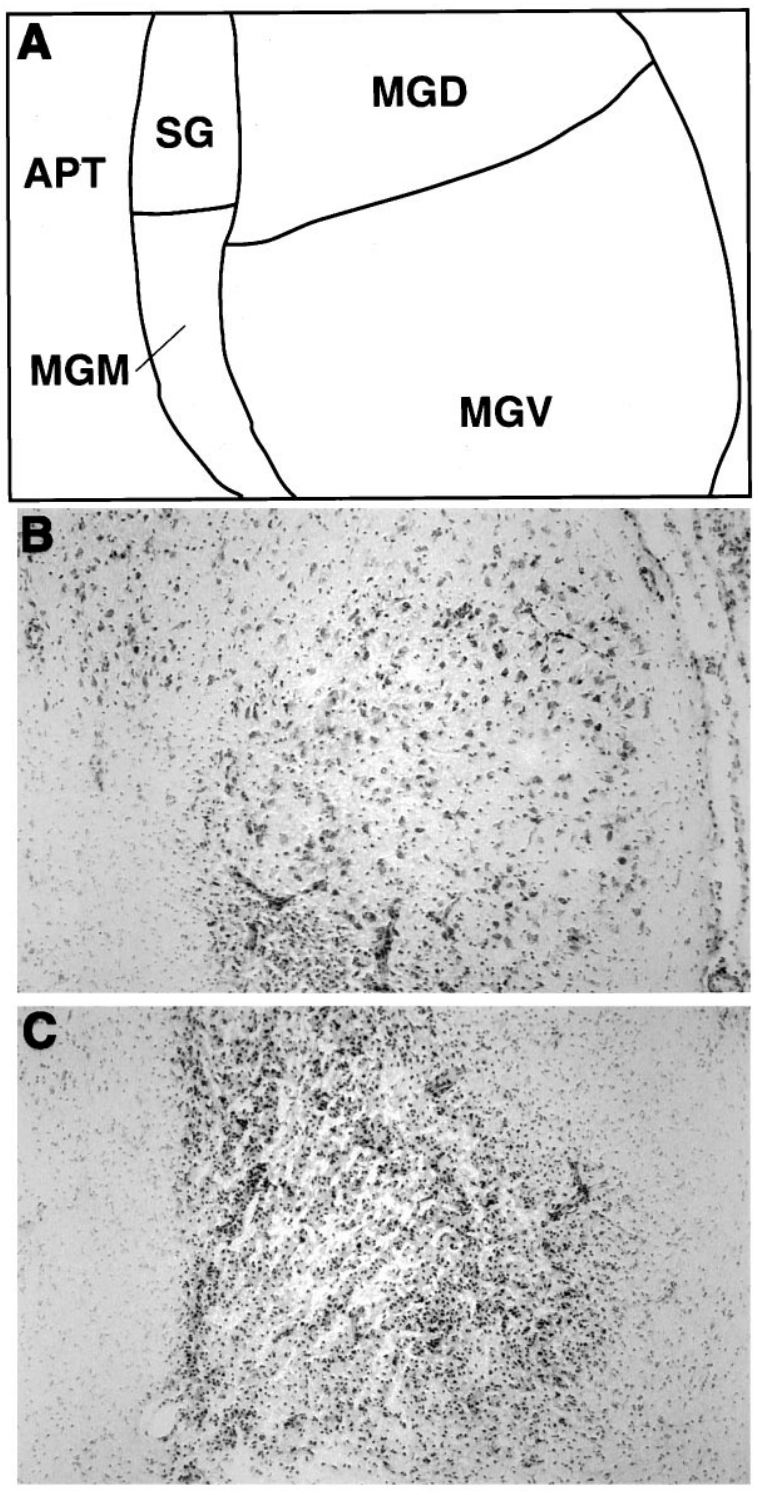

Figure 1. Examples of incomplete and complete excitotoxic lesions of the medial geniculate nuclei produced by ibotenic acid injections, in coronal brain sections stained with cresyl violet. $A$, Line drawing showing the approximate regional boundaries of the various thalamic nuclei depicted in $B$ and $C$. $B$, Brain section from a rat showing incomplete damage of the medial geniculate nuclei, particularly in the ventral subdivision $(M G V) . C$, Brain section from a rat with complete medial geniculate nuclei cell loss. Note that reactive gliosis has replaced the area normally containing neurons in all medial geniculate subdivisions. APT, Anterior pretectal nucleus; $M G D$, dorsal division of the medial geniculate body; $M G M$, medial division of the medial geniculate body; $M G V$, ventral division of the medial geniculate body; $S G$, suprageniculate nucleus.

For restraint stress, rats were wrapped for $30 \mathrm{~min}$ in a flexible white plastic rectangle $(28 \times 20 \mathrm{~cm})$ attached to a $21 \times 8 \times 8 \mathrm{~cm}$ rigid clear Plexiglas frame. Ether stress was produced by placing rats in a 1.0 cubic foot glass jar containing gauzes saturated with diethyl ether for $3 \mathrm{~min}$.

Surgery. Rats were anesthetized by intraperitoneal injections of 50 $\mathrm{mg} / \mathrm{kg}$ sodium pentobarbital (Butler). They were shaved and placed in a Kopf stereotaxic instrument equipped with blunt earbars. The skin overlying the skull was disinfected (Betadine), an incision was made, and small burr holes were drilled through the skull bone to allow penetration of the injector (Hamilton $1 \mu$ l syringe). Bilateral excitotoxic lesions $(n=$ 18) aimed at all auditory subnuclei of the thalamus (all subdivisions of the medial geniculate body, suprageniculate nucleus, and intralaminar nucleus) were produced with two $0.3 \mu \mathrm{l}$ injections of ibotenic acid (10 


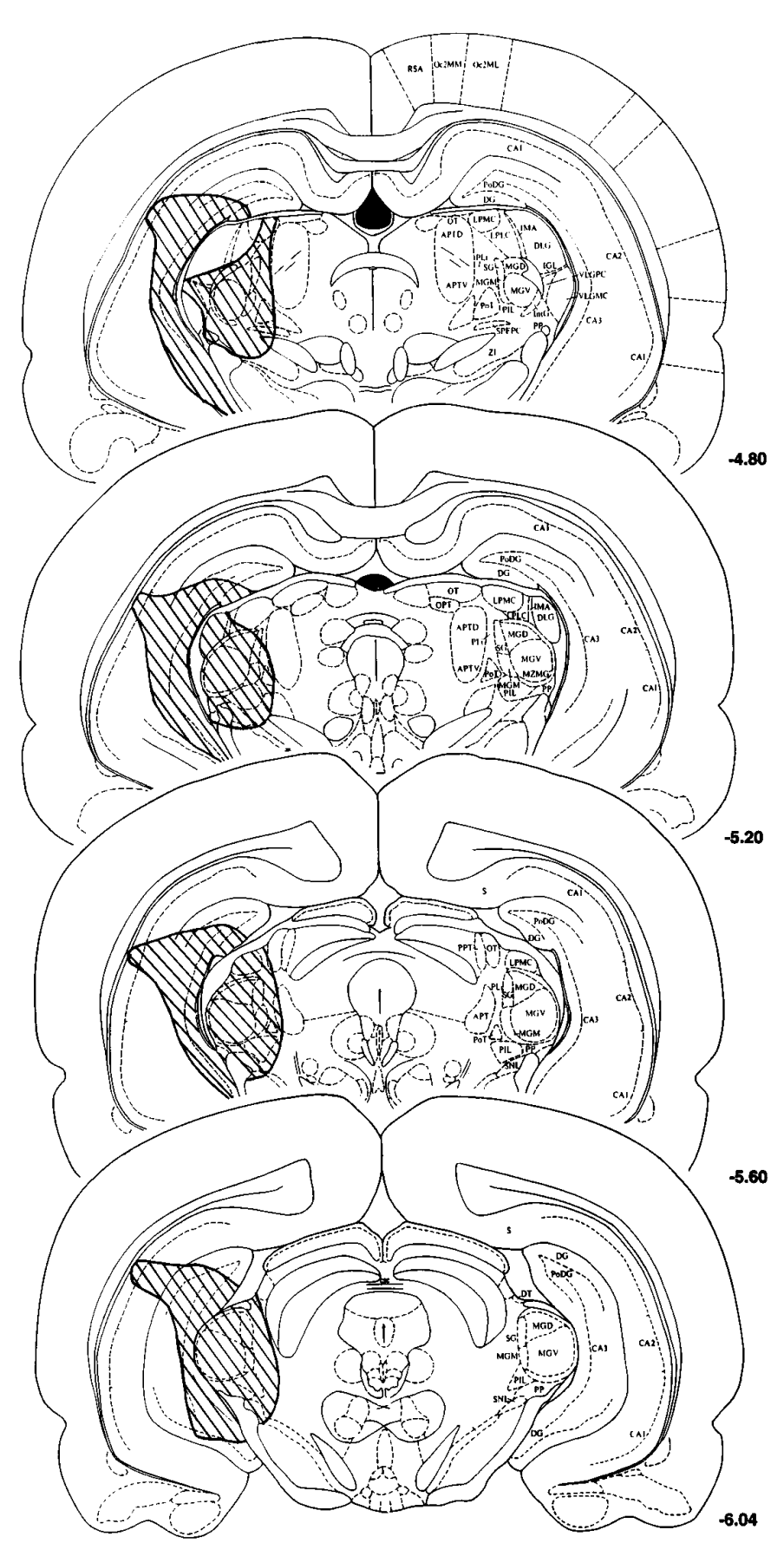

Figure 2. Histological reconstructions of the cell loss (shaded area on the left) induced by ibotenic acid injections in a representative rat sustaining complete lesions of the medial geniculate nuclei. Note the substantial cell loss in the hippocampus, which was similar in rats sustaining complete and incomplete medial geniculate lesions (reconstructions not shown). Cell loss was similar bilaterally, but shown unilaterally here to allow description of regional structures on the right side of each section. Reconstructions were made on photocopies of plates from the rat brain atlas of Paxinos and Watson (1986), with the negative numbers to the right of each section indicating posterior distance from Bregma. APTD, APTV, $A P T$, Anterior pretectal nuclei; $C A 1, C A 2, C A 3$, hippocampal areas; $D L G$, $V L G P C, V L G M C$, dorsal and ventral lateral geniculate nuclei; $D G$, $P o D G$, dentate gyrus; $D T$, dorsal terminal nucleus of the accessory optic tract; $I G L$, intergeniculate leaf; $I M A$, intramedullary area; $I n t G$, intermediate geniculate nucleus; $L P M C, L P L C$, lateral posterior nuclei; $M G D$, $M G M, M G V$, medial geniculate dorsal, medial, and ventral subdivisions; $M Z M G$, marginal zone of the medial geniculate; Oc2MM, Oc2ML, occipital cortex; $O P T$, olivary pretectal nucleus; $O T$, nucleus of the optic tract; $\mu \mathrm{g} / \mu \mathrm{l}$ in $0.1 \mathrm{M}$ sodium phosphate buffer, $\mathrm{pH} 7.4$ ) per side. The injector was lowered into the brain and left in place for $3 \mathrm{~min}$ before and $7 \mathrm{~min}$ after each injection. Following the flat skull coordinate system of Paxinos and Watson (1986), the first injection was made at $5.2 \mathrm{~mm}$ posterior, 3.1 $\mathrm{mm}$ lateral, and $6.8 \mathrm{~mm}$ ventral to Bregma, and the second injection was made at $6.5 \mathrm{~mm}$ posterior, $3.2 \mathrm{~mm}$ lateral, and $6.8 \mathrm{~mm}$ ventral to Bregma. The rate of infusion was $0.05 \mu \mathrm{l} / \mathrm{min}$. After the injections, the scalp incision was closed with surgical stainless steel wound clips, and rats were kept warm and under observation until recovery from anesthesia. The same procedures were followed for sham-operated rats $(n=15)$, except that only the vehicle solution (sodium phosphate buffer) was injected. Eleven rats served as unoperated controls.

Behavioral procedures. Habituation began $24 \mathrm{hr}$ after surgery. This consisted of handling the rats for 3-4 min and then placing them in the experimental cages for $10 \mathrm{~min}$ daily for 6 consecutive d (days 1-6). On day 7 , half of the rats were given a 30 min session of restraint stress, and blood was collected by tail nicks at $0,30,60,90$, and $120 \mathrm{~min}$ after the beginning of restraint. The same procedures were performed on the other half of the rats on day 8 . On day 9, approximately half of the rats (mixed from those receiving restraint on days 7 and 8 ) were given a $3 \mathrm{~min}$ exposure to ether vapor, which was sufficient in all cases to produce anesthesia. Blood was collected via tail nicks 15 min after initiation of ether vapor, a time at which peak corticosterone release in response to ether was reported in a previous study from our laboratory (Vazquez and Akil, 1993). Two additional habituation sessions were given on days 10 and 11 . On day 12 , half of the rats were placed in the experimental boxes for $60 \mathrm{~min}$. In half of these, background noise remained on for the whole session, and in the other half, white noise of $105 \mathrm{~dB}$ was turned on for the last $30 \mathrm{~min}$. Blood was collected via tail nicks immediately after removal of the rats from the experimental cages. The same procedures were performed on day 13 for the second half of the rats. An additional habituation session was given to all rats on day 14 . The same procedures performed on days $12-13$ were performed on days 15 and 16 , with the exception that the rats were exposed to the condition to which they had not been exposed previously. At the end of these sessions, rats were decapitated immediately after removal from the experimental cages; trunk blood, adrenals, and thymus were collected, and the brains were removed rapidly and frozen in chilled isopentane $\left(-40^{\circ} \mathrm{C}\right)$. Four rats that were not handled or exposed to any other procedures served as naive controls and were decapitated immediately after removal from the colony room.

Corticosterone radioimmunoassay. Blood obtained from tail nicks or after decapitation was collected into ice-chilled tubes containing EDTA. Blood samples were centrifuged at $2000 \mathrm{rpm}$ for $10 \mathrm{~min}$, and the resulting plasma was pipetted into chilled $0.5 \mathrm{ml}$ Ependorf microcentrifuge tubes and stored at $-20^{\circ} \mathrm{C}$ until assayed.

Corticosterone was measured by radioimmunoassay using a specific rabbit antibody raised in our laboratory, with $<3 \%$ cross-reactivity with other steroids (Dr. Dana Helmreich, personal communication). Plasma samples were diluted 1:100 in $0.05 \mathrm{~m}$ sodium phosphate buffer containing $0.25 \%$ bovine serum albumin, $\mathrm{pH} 7.4$, and corticosterone was released from binding proteins by heat $\left(70^{\circ} \mathrm{C}, 30 \mathrm{~min}\right)$. Duplicate samples of 200 $\mu \mathrm{l}$ to which $50 \mu \mathrm{l}$ of trace $\left({ }^{3} \mathrm{H}\right.$-corticosterone, Amersham, Arlington Heights, IL; $50 \mathrm{Ci} / \mathrm{mmol}, 10,000 \mathrm{cpm} /$ tube), and $50 \mu \mathrm{l}$ of antibody (final concentration $1: 12,800$ ) were incubated at $4^{\circ} \mathrm{C}$ overnight. The addition of $0.5 \mathrm{ml}$ of chilled $1 \%$ charcoal $/ 0.1 \%$ dextran mixture in buffer for $10 \mathrm{~min}$ at $4^{\circ} \mathrm{C}$ was used to separate bound from free corticosterone and then centrifuged for $10 \mathrm{~min}$ at $3000 \mathrm{rpm}$ (Sorvall RC-5B). The supernatant was poured into $4 \mathrm{ml}$ of scintillation fluid, and bound ${ }^{3} \mathrm{H}$-corticosterone was counted on a Packard CA2000 liquid scintillation analyzer and compared with a standard curve (range, $0-80 \mu \mathrm{g} / \mathrm{dl}$ ). Variability was kept to a minimum $(<5 \%)$ by measuring all samples within the same assay.

In situ hybridization histochemistry and histology. Brains were removed rapidly, frozen in chilled isopentane $\left(-40^{\circ} \mathrm{C}\right)$, and stored at $-80^{\circ} \mathrm{C}$. They were then sliced $(10 \mu \mathrm{m})$ in a Bright cryostat, thaw-mounted onto polylysine-coated slides, and stored at $-80^{\circ} \mathrm{C}$ until they were processed. Sections were fixed in buffered paraformaldehyde $(4 \%)$ for $1 \mathrm{hr}$, rinsed

$P o T$, posterior nucleus, triangular; $P I L$, posterior intralaminar nucleus; $P L i$, posterior limitans nucleus; $P P$, peripeduncular nucleus; $R S A$, retrosplenial cortex; $S$, subiculum; $S G$, suprageniculate nucleus; $S N L$, substantia nigra lateralis; SPFPC, subparafascicular nucleus; ZI, zona incerta. 


\begin{tabular}{|c|c|c|c|c|}
\hline Experimental group & $N$ & $\begin{array}{l}\text { Body } \\
(\mathrm{gm})\end{array}$ & $\begin{array}{l}\text { Adrenals (mg/ } \\
100 \text { gm BW) }\end{array}$ & $\begin{array}{l}\text { Thymus (mg/100 } \\
\text { gm BW) }\end{array}$ \\
\hline Naive & 4 & $415(10)$ & $16(1)$ & $134(11)$ \\
\hline Unoperated & 11 & $414(8)$ & $13(1)$ & $133(9)$ \\
\hline Sham-operated & 15 & $402(8)$ & $15(1)$ & $120(8)$ \\
\hline MGN lesions complete & 9 & $385(7)$ & $15(1)$ & $104(11)$ \\
\hline MGN lesions incomplete & 9 & $408(6)$ & $15(1)$ & $109(9)$ \\
\hline
\end{tabular}

BW, Body weight.

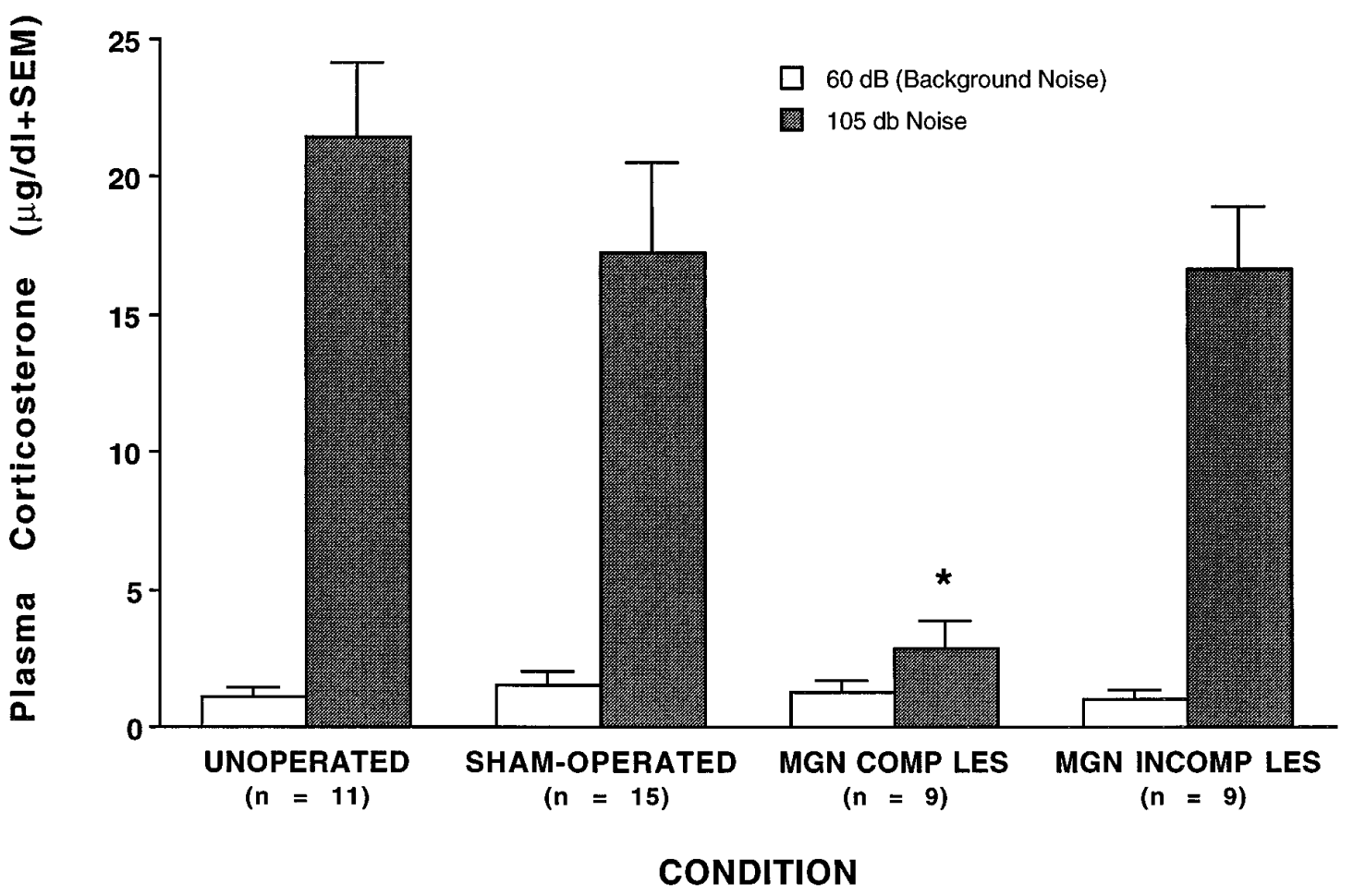

Figure 3. Mean plasma corticosterone $(\mu \mathrm{g} / \mathrm{dl})$ obtained in rats from the various groups [unoperated, sham-operated, medial geniculate nuclei complete lesions (MGN COMP LES), MGN incomplete lesions (MGN INCOMP LES)] $1 \mathrm{hr}$ after cage placement (white bars) or after 30 min of $105 \mathrm{~dB}$ white noise ( gray bars). The SEM is indicated above each bar. The numbers $(n)$ at the bottom indicate the number of rats in each group. ${ }^{*} p<0.05$ compared with all other groups under the $105 \mathrm{~dB}$ noise condition.

with $2 \times$ SSC (sodium citrate), and deproteinated with Proteinase K $(0.1$ $\mu \mathrm{g} / \mathrm{ml}$ ) for $10 \mathrm{~min}$ at $37^{\circ} \mathrm{C}$. Sections were rinsed in $\mathrm{H}_{2} \mathrm{O}$ for $5 \mathrm{~min}$, acetylated in $0.1 \mathrm{M}$ triethanolamine containing $0.25 \%$ acetic anhydride for $10 \mathrm{~min}$, rinsed for $5 \mathrm{~min}$ in $\mathrm{H}_{2} \mathrm{O}$, and dehydrated in alcohols.

${ }^{35} \mathrm{~S}$-labeled cRNA c-fos riboprobes were prepared from cDNA subclones in transcription vectors using standard in vitro transcription methodology. The rat c-fos cDNA clone (courtesy of Dr. T. Curran, St. Jude Children's Research Hospital, Memphis, TN) was subcloned in pGem3Z and cut with HindIII to yield a 680 nucleotide (nt) cDNA template. The rat CRH cDNA clone (courtesy of Dr. R. T. Thompson, University of Michigan) was subconed in pGem $3 Z$ and cut with $X b a \mathrm{I}$ to yield a $770 \mathrm{nt}$ cDNA template. Copy riboprobes were produced in a reaction mixture $\left(120 \mathrm{~min}\right.$ at $\left.37^{\circ} \mathrm{C}\right)$ consisting of $1 \mu \mathrm{g}$ linearized plasmid, $1 \times \mathrm{T} 7$ transcription buffer (BRL, Bethesda, MD), $125 \mu \mathrm{Ci}{ }^{35} \mathrm{~S}-\mathrm{UTP}, 150 \mu \mathrm{M}$ NTPs, 12.5 $\mathrm{mm}$ dithiothreitol, $20 \mathrm{U}$ RNase inhibitor, and $6 \mathrm{U}$ polymerase (T7). Riboprobes were separated from free nucleotides over a Sephadex G50-50 column. Riboprobes were diluted in hybridization buffer to yield $\sim 1.5 \times 10^{6} \mathrm{dpm} / 30 \mu \mathrm{l}$ buffer. The hybridization buffer consisted of $50 \%$ formamide, $10 \%$ dextran sulfate, $3 \times$ SSC, $50 \mathrm{~mm}$ sodium phosphate buffer, $\mathrm{pH}=7.4,1 \times$ Denhardt's solution, and $0.1 \mathrm{mg} / \mathrm{ml}$ yeast tRNA. The hybridization mixture $(30 \mu \mathrm{l})$ was applied to each slide, and sections were coverslipped. Slides were placed in covered plastic boxes lined with filter paper moistened with $50 \%$ formamide in $\mathrm{H}_{2} \mathrm{O}$ and incubated for $12-16 \mathrm{hr}$ at $55^{\circ} \mathrm{C}$. Coverslips were then removed, and slides were rinsed several times in $2 \times$ SSC. Incubation in RNase A $(200 \mu \mathrm{g} / \mathrm{ml})$ followed for $60 \mathrm{~min}$ at $37^{\circ} \mathrm{C}$, and slides were washed successively in $2 \times, 1 \times, 0.5 \times$, and $0.1 \times$ SSC for 5-10 min each, with an additional wash in $0.1 \times$ SSC for 60 $\min$ at $65^{\circ} \mathrm{C}$. Slides were rinsed in fresh $0.1 \times \mathrm{SSC}$, dehydrated in alcohols, and exposed to Kodak BIOMAX MR x-ray film.

Pretreatment with RNase A $\left(200 \mu \mathrm{g} / \mathrm{ml}\right.$ at $37^{\circ} \mathrm{C}$ for $\left.60 \mathrm{~min}\right)$ before hybridization prevented labeling, which served as a control experiment. Another control was provided by hybridizing some sections with the sense cRNA strands, which in all cases did not lead to significant hybridization to tissue sections.

Importantly, three to five slides for a given brain region from each rat included in the study were processed simultaneously to allow direct comparisons in the same regions. Multiple in situ hybridizations were performed at different levels of the brain, with all animals represented to reduce the effects of technical variations within regions. Sections of all rats in the same region were exposed on the same x-ray film to further minimize variations. Semiquantitative analyses were performed on digitized images from $\mathrm{x}$-ray films in the linear range of the gray values obtained from an acquisition system (Northern Light lightbox model B 95, a CCD Pulnix TV camera model TM-745 fitted with a Nikkor $55 \mathrm{~mm}$ lens, connected to a graber card on board a Macintosh Quadra 840AV, captured with National Institutes of Health Image v1.59). Signal pixels of a region of interest were defined as having a gray value of $3.5 \mathrm{SD}$ above the mean gray value of a cell-poor area close to the region of interest. 


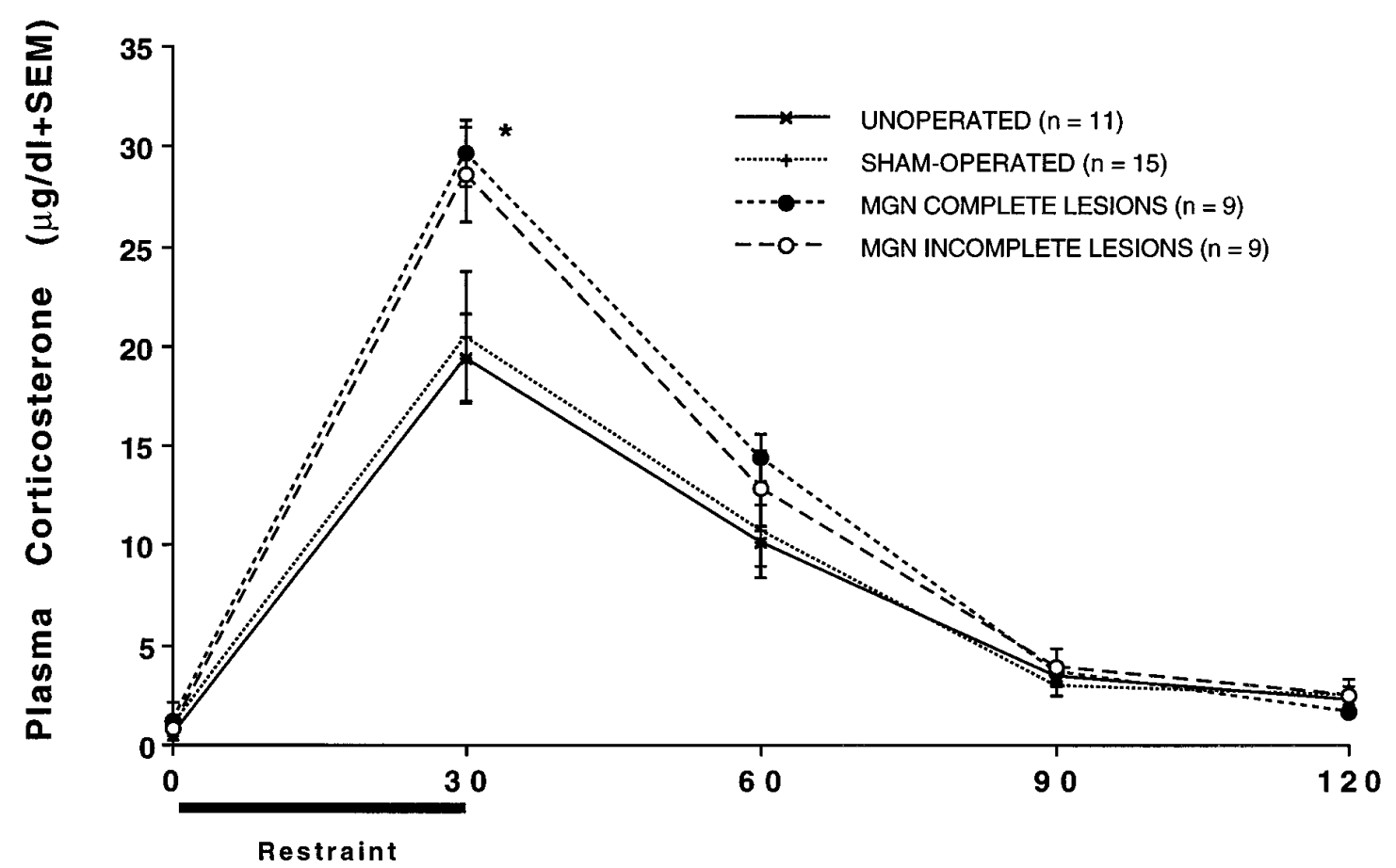

Time (min)

Figure 4. Mean plasma corticosterone ( $\mu \mathrm{g} / \mathrm{dl})$ obtained in rats from the various groups (indicated in graph) immediately before (time 0$)$ and at several times $(30,60,90,120 \mathrm{~min})$ after initiation of $30 \mathrm{~min}$ restraint stress. The SEM is indicated at each time point. ${ }^{*} p<0.05$ compared with unoperated and sham-operated rats.

\begin{tabular}{lcl}
\hline $\begin{array}{l}\text { Table 2. Mean corticosterone levels } 15 \\
( \pm \text { mEM })\end{array}$ & $N$ & $\begin{array}{l}\text { Corticosterone } \\
(\mu \mathrm{g} / \mathrm{dl})\end{array}$ \\
Experimental group & 6 & $18.7(9)$ \\
Unoperated & 7 & $20.2(8)$ \\
Sham-operated & 4 & $21.7(11)$ \\
MGN lesions complete & 5 & $21.2(9)$ \\
MGN lesions incomplete & & \\
\hline
\end{tabular}

The number of pixels and the average gray values above the set background were then computed for each region of interest and multiplied, giving an integrated densitometric measurement. An average of three to six measurements were made on different sections, for each region of interest, and these values were further averaged to get a single integrated density value per region for each rat. Slides undergoing in situ hybridization were stained with cresyl violet and used extensively in the determination of regional boundaries on the digitized images. Sections in the region of the lesions were fixed in paraformaldehyde (4\%) for $60 \mathrm{~min}$, rinsed in $\mathrm{H}_{2} \mathrm{O}$, and stained with cresyl violet for determination of the lesioned areas.

Statistics. One-way ANOVA was performed on body, adrenals, and thymus weights. Mixed design ANOVAs were used to analyze plasma corticosterone levels after restraint, ether, and noise stress. These were followed by post hoc Tukey multiple mean comparisons to determine the source of significant effects.

For purposes of statistical analysis, the mean c-fos and CRHintegrated density values were transformed to natural logarithm values to reduce between-group variances observed in some regions. One-way ANOVAs were performed on the transformed mean integrated densities obtained from each region in which c-fos mRNA or CRH mRNA was measured. This was followed by Tukey's post hoc multiple mean comparisons to determine more exactly the source of the differences obtained with the initial ANOVA. Statistical significance in all instances was set to $p=0.05$.

\section{RESULTS}

\section{Histology}

Histological verifications of the lesions induced with the fibersparing excitotoxin ibotenic acid revealed that nine rats sustained relatively complete and bilateral loss of neurons $(>90 \%)$ in all medial geniculate subnuclei, the suprageniculate nucleus, and the posterior intralaminar nucleus, whereas the other nine rats displayed sparing in one or more of these nuclei unilaterally or bilaterally, as exemplified in Figure 1. All rats that sustained complete or incomplete medial geniculate nuclei lesions also sustained significant cell loss in the hippocampus, particularly the dorsal dentate gyrus and CA3 region, as represented in reconstructions of the lesioned areas in Figure 2. Additional but more variable cell loss was observed in the lateral geniculate nucleus, the lateral posterior nucleus, the posterior thalamic nucleus, the parvocellular part of the subparafascicular nucleus, the peripeduncular nucleus, and the substantia nigra pars lateralis. On the basis of histological verifications, the lesioned rats were divided into the complete $(n=9)$ or incomplete $(n=9)$ medial geniculate nuclei-lesioned groups.

\section{Body, adrenals, and thymus weights and mpPVN CRH mRNA levels}

Because of the possible chronicity of the stress induced by the excitotoxic lesions, indices normally associated with chronic stress, including body weight measured immediately before euthanesia, wet adrenals and thymus weights, and CRH mRNA levels in the parvocellular neurons of the paraventricular nucleus of the hypothalamus were evaluated. No significant signs of chronic stress were obtained from the ANOVAs performed on body, adrenals, or thymus weights: $F_{(4,43)}=1.90,2.55$, and 1.82; all $p$ values $>0.05$, respectively (Table 1$)$. The integrated densi- 


\begin{tabular}{|c|c|c|c|c|}
\hline \multirow[b]{2}{*}{ Brain region } & \multicolumn{4}{|c|}{ Experimental group } \\
\hline & Naive & Unoperated & Sham-operated & MGN lesions \\
\hline \multicolumn{5}{|l|}{ Forebrain } \\
\hline Nucleus accumbens core* & $11(2.4)$ & $141^{* *}(17)$ & $131^{* *}(18)$ & $57^{* * *}(15)$ \\
\hline Nucleus accumbens shell* & $7.5(2.9)$ & $110 * *$ & $121 * *$ & $44^{* * *}(14)$ \\
\hline BNST medial* & $3.4(2.2)$ & $69^{* *}(5.9)$ & $80 * *$ & $5.5(2.6)$ \\
\hline BNST ventral* & $3.4(2.1)$ & $44 * *(3.5)$ & $44^{* *}(5.0)$ & $6.0(1.9)$ \\
\hline Caudate nucleus dorsal* & $22(3.7)$ & $76^{* * *}(12)$ & $64^{* * *} \quad(17)$ & $37(8.7)$ \\
\hline Caudate nucleus ventral & $7.6(1.4)$ & $8.3(1.9)$ & $11(5.1)$ & $6.3(0.4)$ \\
\hline Dorsal endopiriform nucleus* & $15(1.8)$ & $109 * *(5.4)$ & $101 * * \quad(12)$ & $51^{* * *}(6.6)$ \\
\hline Medial septum & $7.8(4.8)$ & $27(6.6)$ & $33(12)$ & $13(3.7)$ \\
\hline Lateral septum* & $63(62)$ & $422 * * * \quad(26)$ & $486^{* * *}(41)$ & $92(52)$ \\
\hline Septohypothalamic nucleus* & $6.6(3.4)$ & $175^{* *}(25)$ & $205^{* *}(33)$ & $29(21)$ \\
\hline \multicolumn{5}{|l|}{ Amygdala } \\
\hline Anterior cortical nuclei* & $45(8.4)$ & $82 * * *(6.3)$ & $76 \quad(11)$ & $53(5.4)$ \\
\hline Basolateral nucleus* & $32(5.8)$ & $93^{* *}(12)$ & $63(11)$ & $36(1.0)$ \\
\hline Lateral nucleus* & $4.9(0.7)$ & $49^{* *}(2.8)$ & $35^{* * *}(6.9)$ & $20^{* * *}(6.0)$ \\
\hline Central nucleus* & $10(1.7)$ & $13(2.4)$ & $16^{* * * *}(2.8)$ & $5.0(1.1)$ \\
\hline Medial nucleus* & $12(0.6)$ & $68 * * *(8.2)$ & $85^{* * *}(44)$ & $23(5.1)$ \\
\hline \multicolumn{5}{|l|}{ Hippocampus } \\
\hline Dentate gyrus dorsal & $31(5.8)$ & $42(7.5)$ & $35(3.7)$ & $20(1.6)$ \\
\hline Dentate gyrus ventral* & $4.6(2.9)$ & $44^{* * *} \quad(11)$ & $41^{* * *} \quad(11)$ & $13(8.2)$ \\
\hline CA1 & $16(2.6)$ & $30(5.4)$ & $23(5.4)$ & $22(2.1)$ \\
\hline $\mathrm{CA} 2$ & $6.7(2.1)$ & $7.2(1.8)$ & $4.6(0.8)$ & $7.0(2.2)$ \\
\hline CA3* & $31(2.8)$ & $108^{* * *}(14)$ & $87^{* * *}(8.7)$ & $88^{* * *}(14)$ \\
\hline \multicolumn{5}{|l|}{ Cortex } \\
\hline Cingulate* & $150 \quad(39)$ & $1540 * * *(153)$ & $1126^{* * *}(180)$ & $1089^{* * *}(222)$ \\
\hline Claustrum* & $477(182)$ & $1106^{* * *}(179)$ & $902 * * * \quad(45)$ & $806(152)$ \\
\hline Frontal & $355 \quad(87)$ & $590(103)$ & $416 \quad(74)$ & $428(159)$ \\
\hline Infralimbic* & $20(4.6)$ & $302^{* * *}(50)$ & $276^{* * *}(42)$ & $261^{* * *}$ \\
\hline Lateralorbital & 314 (75) & $598(111)$ & $597 \quad(64)$ & $543(181)$ \\
\hline Occipital (visual)* & 1226 (97) & $2821 * * *(198)$ & $2267 * * *(387)$ & $1772(196)$ \\
\hline Parietal & $2165(178)$ & $2678(181)$ & $2608(417)$ & $2045(463)$ \\
\hline Perirhinal* & $30(8.3)$ & $178^{* * *}(16)$ & $128^{* * *}(23)$ & $114^{* * *}(21)$ \\
\hline Piriform & $618 \quad(53)$ & 873 (87) & $801 \quad(65)$ & $754(118)$ \\
\hline Temporal (auditory)* & $883(192)$ & $2085^{* *}(43)$ & $1764 * *(299)$ & $860(185)$ \\
\hline \multicolumn{5}{|l|}{ Hypothalamus } \\
\hline Anterior area* & $16(0.5)$ & $144^{* *}(17)$ & $139 * * * \quad(24)$ & $74^{* * *}(4.4)$ \\
\hline Anteroventral preoptic area* & $15(8.6)$ & $103^{* *}(12)$ & $96^{* *}(14)$ & $23(7.2)$ \\
\hline Dorsomedial nucleus* & $34(1.5)$ & $335^{* *}(20)$ & $345^{* *}(47)$ & $153^{* * *}(55)$ \\
\hline Lateral nucleus* & $9.2(6.1)$ & $117^{* * *}(26)$ & $113^{* * *}(17)$ & $42(24)$ \\
\hline Lateral preoptic area* & $10(3.3)$ & $187 * *(23)$ & $214 * * \quad(23)$ & $67^{* * *}(32)$ \\
\hline Medial preoptic area & $14(9.5)$ & $19(2.9)$ & $35(12)$ & $15(5.2)$ \\
\hline Medial preoptic nucleus & $5.3(1.2)$ & $12(2.7)$ & $19(4.9)$ & $6.2(2.9)$ \\
\hline Paraventricular nucleus* & $12(5.3)$ & $142 * *(32)$ & $159^{* *}(15)$ & $27(14)$ \\
\hline Supramammillary nucleus* & $21(9.2)$ & $347 * *(13)$ & $335^{* *}(29)$ & $93^{* * *}(53)$ \\
\hline Ventromedial nucleus* & $1.3(0.2)$ & $24 * * *(6.6)$ & $25^{* * *}(8.8)$ & $7.1^{* * *}(0.3)$ \\
\hline \multicolumn{5}{|l|}{ Thalamus } \\
\hline Anterodorsal nucleus & 111 & $58(7.8)$ & $89(20)$ & $98(8.7)$ \\
\hline Anteroventral nucleus* & $45(9.0)$ & $282^{* * *}(24)$ & $268^{* * *}(45)$ & $168^{* * *}(26)$ \\
\hline Central nuclei* & 92 (37) & $549 * * * \quad(53)$ & $401 * * * \quad(76)$ & $477 * * * \quad(51)$ \\
\hline Mediodorsal nucleus* & $3.9(1.6)$ & $72 * * *(6.2)$ & $77^{* * *} \quad(20)$ & $63^{* * *}(15)$ \\
\hline Paraventricular nucleus* & $92(5.3)$ & $353^{* * *}(24)$ & $389^{* * *} \quad(38)$ & $271^{* * *}$ \\
\hline Ventroposterolateral nucleus & $184(100)$ & $152(11)$ & 185 (29) & $207 \quad(52)$ \\
\hline Subparafascicular nucleus* & $13(7.1)$ & $124 * * * \quad(36)$ & $156^{* * *}(19)$ & $130^{* * *} \quad(13)$ \\
\hline
\end{tabular}


Table 3. Mean integrated densities (/100 \pm SEM) $($ continued $)$

\begin{tabular}{|c|c|c|c|c|}
\hline \multirow[b]{2}{*}{ Brain region } & \multicolumn{4}{|c|}{ Experimental group } \\
\hline & Naive & Unoperated & Sham-operated & MGN lesions \\
\hline \multicolumn{5}{|l|}{ Midbrain, pons, brainstem } \\
\hline Dorsolateral central gray* & $15 \quad(2.2)$ & $119 * * *$ & $126^{* * *} \quad(31)$ & $93^{* * *}(35)$ \\
\hline Lateroventral central gray* & $(9.0)$ & $75^{* * *}$ & $110^{* * *}$ & $45 \quad(21)$ \\
\hline Cochlear nuclei* & $59 \quad(5.3)$ & $701 * * * \quad(141)$ & $519^{* * *}$ & $531^{* * *}$ \\
\hline Cuneiform nucleus* & $15 \quad(3.3)$ & $78^{* * *} \quad(15)$ & $75^{* * *} \quad(19)$ & $68^{* * *}(7.5)$ \\
\hline Inferior colliculus* & $650 \quad(85)$ & $2882^{* * *}(106)$ & $2330^{* * *}(319)$ & $2590 * * *(180)$ \\
\hline Nucleus lateral lemniscus* & $22 \quad(5.2)$ & $524 * * * \quad(85)$ & $389^{* * *} \quad(83)$ & $350^{* * *}(100)$ \\
\hline Superior olivary complex* & $(6.0)$ & $496 * * * \quad(68)$ & $387^{* * *}$ & $420^{* * *}(85)$ \\
\hline Locus coeruleus* & $1.7 \quad(1.2)$ & $11^{* * *} \quad(2.8)$ & $14^{* * *} \quad(8.5)$ & $9.3(3.7)$ \\
\hline Raphe dorsal & $8.7 \quad(2.1)$ & 11 (1.8) & $23 \quad(8.3)$ & $12(1.0)$ \\
\hline Raphe medial* & $1.4 \quad(0.7)$ & $8.0^{* * *} \quad(0.3)$ & $10^{* * *} \quad(1.5)$ & $5.3(0.8)$ \\
\hline Dorsal tegmental nucleus & $13 \quad(5.0)$ & $25 \quad(4.4)$ & $31 \quad(6.3)$ & $34(5.7)$ \\
\hline Laterodorsal tegmental nucleus & $17 \quad(7.0)$ & $35 \quad(2.8)$ & 31 & $32(9.2)$ \\
\hline Ventral tegmental nucleus & $13 \quad(2.9)$ & $19 \quad(0.9)$ & $23 \quad(4.2)$ & $25(6.6)$ \\
\hline \multicolumn{5}{|l|}{ Cerebellum } \\
\hline Lobules (1-10) & $6610(1392)$ & $6002(1177)$ & $6534(1918)$ & $5586(453)$ \\
\hline Flocculus* & 253 & $1400^{* * *}(174)$ & $1554 * * * \quad(364)$ & $1044^{* * *}(265)$ \\
\hline
\end{tabular}

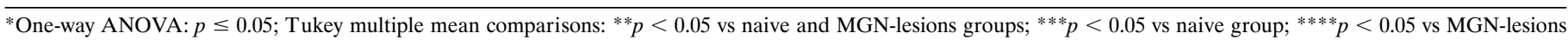
group.

tometric levels of CRH mRNA were $6420( \pm 749)$ for the naives $(n=3), 5866( \pm 605)$ for the unoperated $(n=6), 5447( \pm 914)$ for the sham-operated $(n=6)$, and $6311( \pm 994)$ for the auditory thalamic-lesioned $(n=3)$ rats, and did not differ among any of the groups: $F_{(3,14)}=0.43 ; p>0.05$.

\section{Corticosterone}

The increase in corticosterone levels induced by loud noise was blocked in rats sustaining complete lesions of the medial geniculate nuclei, as indicated in Figure 3. Noise-induced corticosterone release was blocked only in the complete lesions group: $F_{(3,40)}=$ 7.12; $p<0.001$ (Tukey's, $p<0.05$ ). The corticosterone levels in the $55 \mathrm{~dB}$ background noise condition were not different among groups: $F_{(3,40)}=0.29 ; p>0.05$.

The reduction in corticosterone levels in response to loud noise could not be attributed to gross nonspecific effects of the lesions after corticosterone release in response to all stressors. For instance, as depicted in Figure 4, rats sustaining complete or incomplete medial geniculate lesions displayed high levels of corticosterone after 30 min restraint stress. In fact, the corticosterone levels of both lesioned groups were significantly higher than those of the unoperated and sham-operated rats at the $30 \mathrm{~min}$ time point: $F_{(3,40)}=3.70 ; p<0.05$ (Tukey's, $p<0.05$ ). The return to near basal corticosterone levels after restraint was very similar in all groups (see Fig. 4), suggesting relatively normal feedback inhibition in lesioned rats. Likewise, the levels of corticosterone in response to a $3 \mathrm{~min}$ exposure to ether was reliable but not different among any of the groups: $F_{(3,18)}=0.92 ; p>0.05$, as reported in Table 2 .

\section{c-fos mRNA induction}

In situ hybridization of c-fos mRNA was performed on sections from 18 rat brains to determine the changes in regional activity produced by medial geniculate nuclei lesions in response to audiogenic stress. The brains of six unoperated and six shamoperated rats, randomly chosen from those exposed to loud noise on the last day, were processed. Only three of the nine rats found to sustain complete medial geniculate lesions after histological verification had been exposed to noise on the last day, and these were processed in addition to sections from three naive rat brains.

Unoperated and sham-operated rats displayed a broad regional pattern of c-fos mRNA induction $30 \mathrm{~min}$ after the initiation of 105 $\mathrm{dB}$ white noise exposure, as presented in Table 3 . This regional pattern of c-fos mRNA induction in the unoperated and shamoperated rats was similar to that observed in our previous study (Campeau and Watson, 1997). More than half (44) of the 62 brain regions analyzed semiquantitatively by integrated densitometry exhibited statistically significant c-fos mRNA induction in one or more of the experimental groups, compared with the naive rats (ANOVAs, $p<0.05$ ). With few exceptions (4), the regional c-fos mRNA induction in sham-operated rats was statistically indistinguishable from that of the unoperated rats (see Table 3). Representative examples of c-fos mRNA induction in the unoperated, sham-operated, and complete medial geniculate nuclei-lesioned rats after $105 \mathrm{~dB}$ noise exposure are presented at seven levels of the neuraxis in Figures 5 and 6.

c-fos mRNA induction in the complete medial geniculatelesioned rats was significantly different in comparison with the unoperated and sham-operated rats in several brain regions. First, c-fos mRNA induction in the lesioned rats was reliably blocked in six areas that demonstrated significant induction in the unoperated and sham-operated rats. These included the anterior medial and ventral bed nucleus of the stria terminalis, the septohypothalamic nucleus, the anteroventral preoptic area, the paraventricular hypothalamic nucleus, and the temporal (auditory) cortex. An example of c-fos mRNA induction in the unoperated and shamoperated rats and its blockade in lesioned rats is depicted in magnified sections of the hypothalamic paraventricular nucleus in Figure 7. Standard scores ( $z$ scores) computed from the raw integrated densitometric values for each of these regions are illustrated in Figure 8 to help visualize and compare the group variations without the regional differences in overall c-fos mRNA induction. Several additional regions showing significant c-fos 

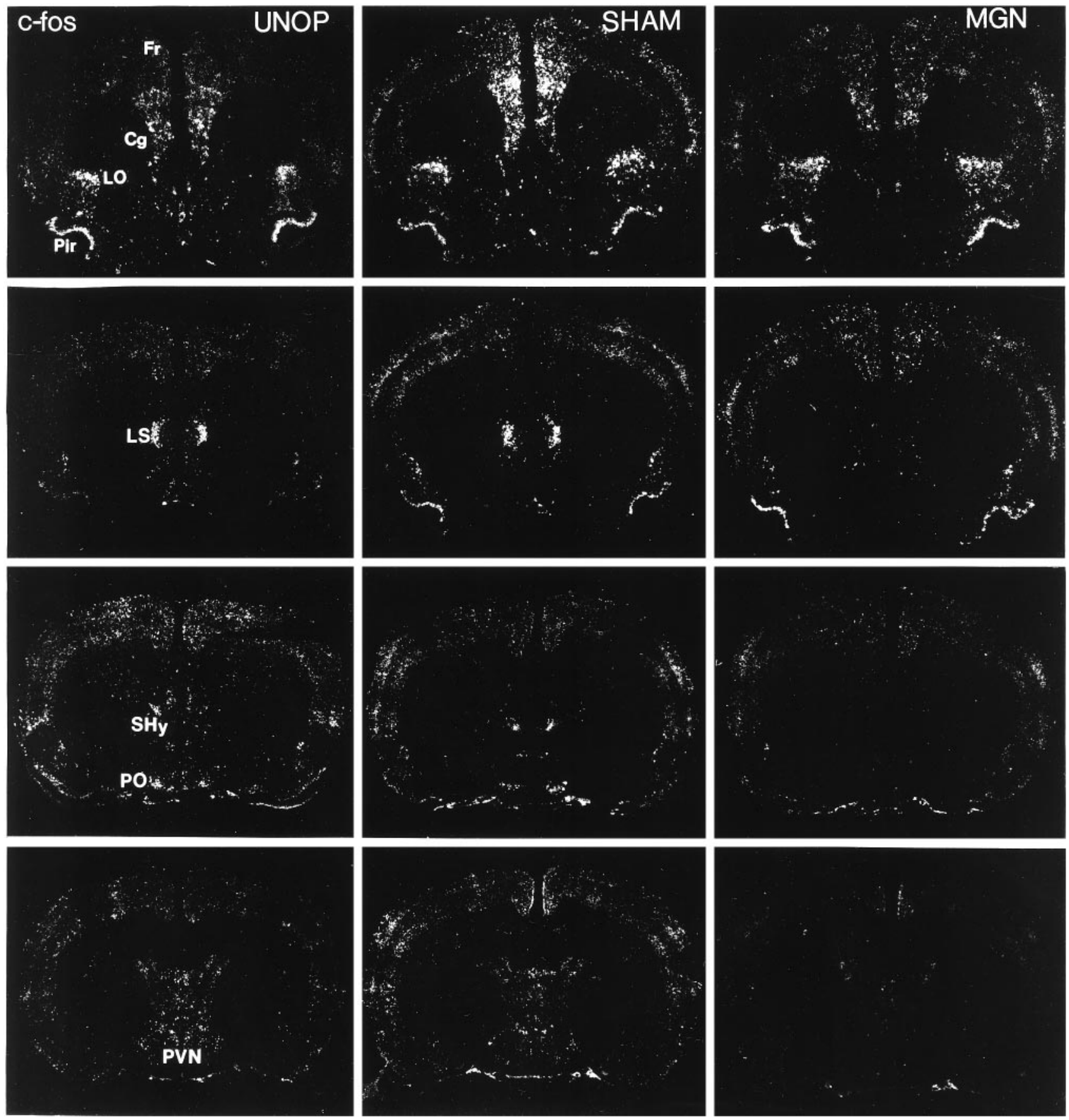

Figure 5. Representative autoradiographic coronal sections processed for c-fos mRNA in situ hybridization in rats of the unoperated (UNOP), sham-operated (SHAM), and complete medial geniculate nuclei-lesioned (MGN) groups exposed to $105 \mathrm{~dB}$ white noise on the last experimental day. Note the reduction in c-fos mRNA induction in the ventral lateral septum $(L S)$, septohypothalamic nucleus $(S H y)$, anteroventral preoptic area $(P O)$, and paraventricular hypothalamic nucleus $(P V N)$ in the MGN rat compared with the UNOP and SHAM rats. Similar c-fos induction levels were observed, however, in rats from the three groups in the frontal $(\mathrm{Fr})$, cingulate $(\mathrm{Cg})$, lateralorbital $(\mathrm{LO})$, and piriform $(\mathrm{Pir})$ cortex.

mRNA induction in the unoperated and sham-operated rats did not show reliable induction in the lesioned rats. The claustrum, occipital cortex, dorsal part of the caudate nucleus, lateral septum, medial nucleus of the amygdala, ventral dentate gyrus, lateral hypothalamic nucleus, lateroventral central gray, locus coeruleus, and median raphe were among these regions (see Table 3).

A large number of regions in the complete medial geniculate nuclei-lesioned rats displayed either reliable, but reduced, or comparable levels of c-fos mRNA induction compared with unoperated and sham-operated rats. Intermediate c-fos mRNA induction in the lesioned rats was observed in the nucleus accumbens core and shell, the dorsal endopiriform nucleus, the hypothalamic dorsomedial nucleus, the lateral preoptic area, and the supramammillary nucleus. Figure 9 presents these regions in standardized ( $z$ scores) forms. Statistically indistinguishable c-fos mRNA induction in several regions (17) of the three experimental groups was observed in many cortical (cin- 

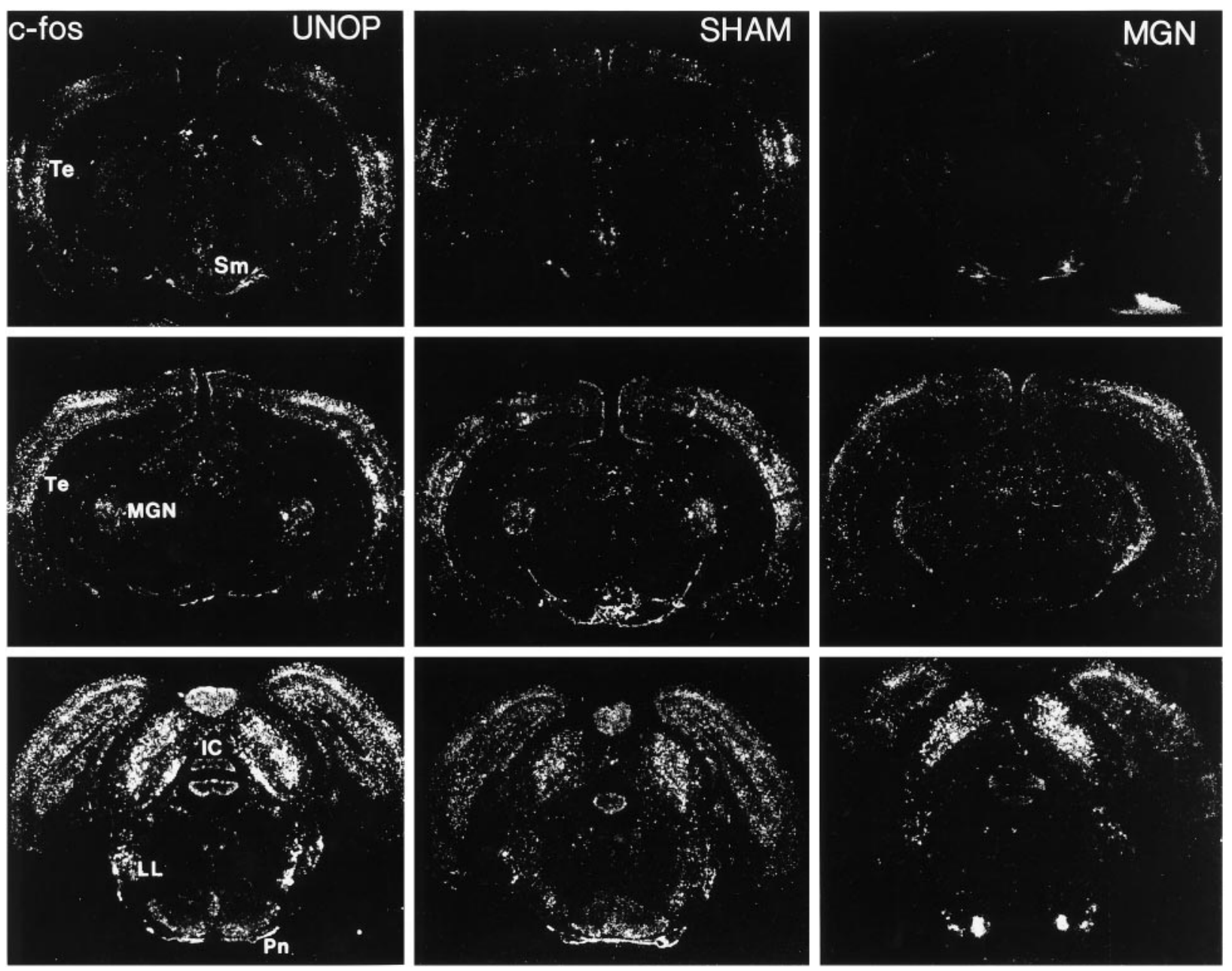

Figure 6. Representative autoradiographic coronal sections processed for c-fos mRNA in situ hybridization in rats of the unoperated (UNOP), sham-operated (SHAM), and complete medial geniculate nuclei-lesioned (MGN) groups exposed to $105 \mathrm{~dB}$ white noise on the last experimental day. Note the reduction in c-fos mRNA induction in the auditory cortex $(\mathrm{Te})$ and supramammillary nucleus $(\mathrm{Sm})$. Similar c-fos induction levels were observed, however, in the inferior colliculus $(I C)$, nuclei of the lateral lemniscus $(L L)$, and pontine nuclei $(P n)$.

gulate, infralimbic, and perirhinal), thalamic (anteroventral, central, mediodorsal, paraventricular, and subparafascicular nuclei), and brainstem auditory regions (cochlear nuclei, inferior colliculus, nuclei of the lateral lemniscus, and superior olivary complex). Additional areas included the hippocampal CA3 region, the ventromedial hypothalamic nucleus, the dorsolateral central gray, the cuneiform nucleus, and the cerebellar flocculus. Some of these regions are presented in standardized scores in Figure 10.

\section{DISCUSSION}

The results of this experiment indicated that loud noise reliably induces the release of corticosterone, as shown previously (Henkin and Knigge, 1963; Collu and Jequier, 1976; Borrell et al., 1980; Armario et al., 1984; Irwin et al., 1989; Segal et al., 1989; Britton et al., 1992; Campeau and Watson, 1997), and that this can be blocked by lesions of the medial geniculate nuclei. Furthermore, the disruption of the HPA activation to audiogenic stress was relatively specific, because corticosterone release in response to restraint or ether stressors was not abolished in the lesioned rats.

The lesion completeness requirement for the blockade of cor- ticosterone release induced by loud noise was suggested by the finding that neuronal sparing in any of the medial geniculate subnuclei was associated with audiogenic stress-induced corticosterone release similar to that of sham-operated controls. In our previous study, we observed reliable c-fos mRNA induction in response to loud noise in several nuclei of the auditory thalamus, including the ventral and dorsal divisions of the medial geniculate body, and particularly in the medial nucleus of the medial geniculate body and the posterior intralaminar nucleus (Campeau and Watson, 1997). All of these subnuclei were consistently lesioned in rats judged to have complete auditory thalamic lesions. Although the spared areas of the incompletely lesioned rats could provide important information regarding the efferent pathway activated by loud noise, sparing was not discrete and consistent enough to specify any particular auditory thalamic subnuclei involvement. A more precise role for any auditory thalamic subnuclei in audiogenic stress could only be resolved with additional studies attempting to specifically disrupt different subnuclei. The fact that the medial nucleus of the medial geniculate body, the suprageniculate nucleus, and the posterior intralaminar nucleus have been linked to auditory emotional learning (LeDoux et al., 

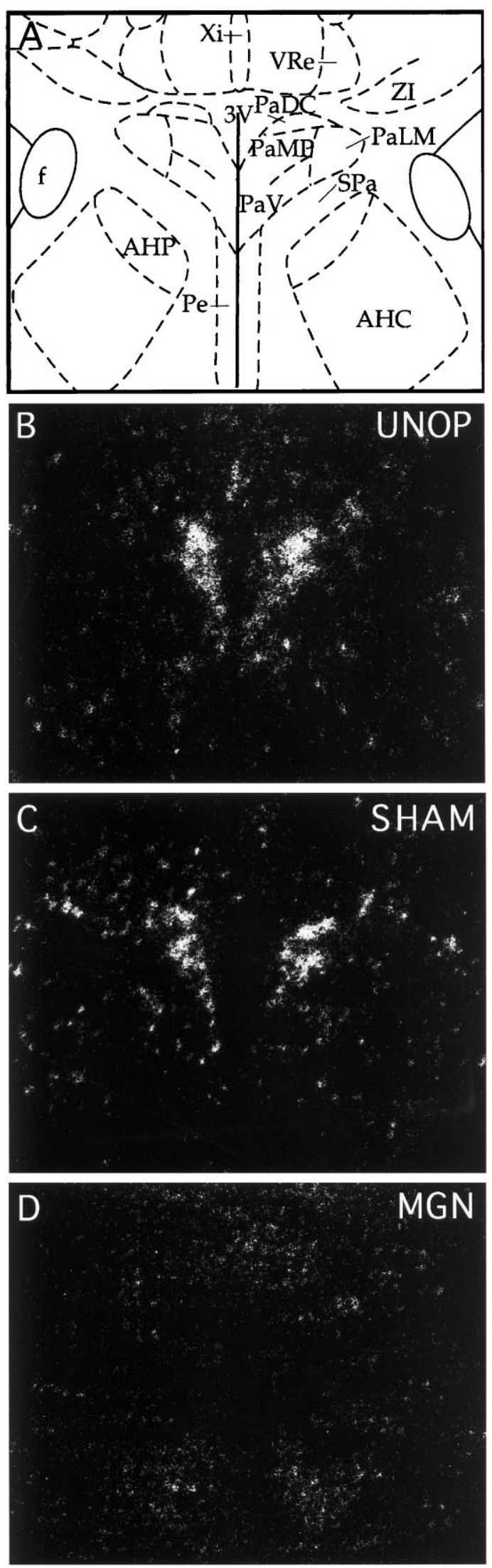

Figure 7. Representative autoradiographic coronal sections processed for c-fos mRNA in situ hybridization magnified in the region of the paraventricular nucleus of the hypothalamus. $A$, Line drawing showing
1984, 1991; Campeau and Davis, 1995) raises the possibility that these same nuclei might also be critically involved in audiogenic stress-induced activation of the HPA axis.

That the lesions did not produce a severe and nonspecific general disruption of HPA activation to all stressful events was suggested by the finding that restraint and ether stress reliably increased corticosterone levels in the complete medial geniculate nuclei-lesioned rats. The higher levels of corticosterone observed in response to restraint in the lesioned rats, regardless of medial geniculate lesions completeness, might be explained by the concomitant and similar hippocampal damage produced in these animals. Enhanced or prolonged release of corticosterone to restraint, but not to ether, has been reported previously in hippocampectomized rats (Fendler et al., 1961; Knigge, 1961; Herman et al., 1995). In addition, as suggested by the lack of differences in body, adrenals, or thymus weights, in the levels of hypothalamic $\mathrm{CRH}$ mRNA, or in the basal levels of corticosterone measured before restraint (time 0 ), it seems unlikely that the specific disruption of audiogenic stress was attributable to the chronic or sustained stress produced by the surgery, lesions, or other aspects of the present experimental protocol. Together, these findings indicate that the medial geniculate nuclei are part of a necessary circuit involved in activation of the HPA axis by audiogenic stress, presumably via one or more of their ascending forebrain efferents. Because there are no reported descending efferents from the medial geniculate nuclei (LeDoux et al., 1985), it is unlikely that the lesion effects observed in the present study could have been produced because the lesions disrupted descending midbrain or brainstem efferents from the medial geniculate nuclei.

A previous study reported that mammillary peduncular electrolytic lesions or posterior hypothalamic deafferentation in rats inhibited corticosterone release in response to $30 \mathrm{~min}$ of a ringing alarm of an unspecified intensity or frequency (Feldman et al., 1972). These lesions were suggested to block an efferent pathway from the reticular brainstem to the hypothalamus. In view of our findings, however, it is possible that the lesions reported by Feldman and coworkers disrupted acoustic projections to the medial geniculate nuclei. Additional studies will be required to determine the possible role of direct brainstem projections to the paraventricular hypothalamic nucleus with the audiogenic stressor used in the present study.

Medial geniculate nuclei disruption altered the regional pattern of c-fos mRNA induction in response to audiogenic stress, which was strongly related to the type of regional pattern observed in our previous study (Campeau and Watson, 1997). For instance, c-fos mRNA induction in several cortical, thalamic, and brainstem regions obtained in the unoperated and sham-operated rats was also observed at comparable or slightly reduced levels in the

$\leftarrow$

the approximate regional boundaries of the various hypothalamic nuclei at the levels depicted in $B, C$, and $D$. Brain sections from unoperated $(U N O P ; B)$, sham-operated (SHAM;C), and complete medial geniculatelesioned $(M G N ; D)$ rats. Note the absence of c-fos mRNA in the paraventricular nucleus of the lesioned rat $(D) 30$ min after audiogenic stress. $A H C$, Anterior hypothalamic area, central; $A H P$, anterior hypothalamic area, posterior; $f$, fornix; $P a D C$, paraventricular nucleus, dorsal cap; $P a L M$, paraventricular nucleus, lateral magnocellular; $P a M P$, paraventricular nucleus, medial parvocellular; $\mathrm{PaV}$, paraventricular nucleus, ventral; $P e$, periventricular nucleus; $S P a$, subparaventricular nucleus; $V R e$, ventral reuniens nucleus; $X i$, xiphoid thalamic nucleus; $Z I$, zona incerta; $3 \mathrm{~V}$, third ventricle. 


\section{Brain regions where MGN lesions blocked c-fos mRNA induction to audiogenic stress}

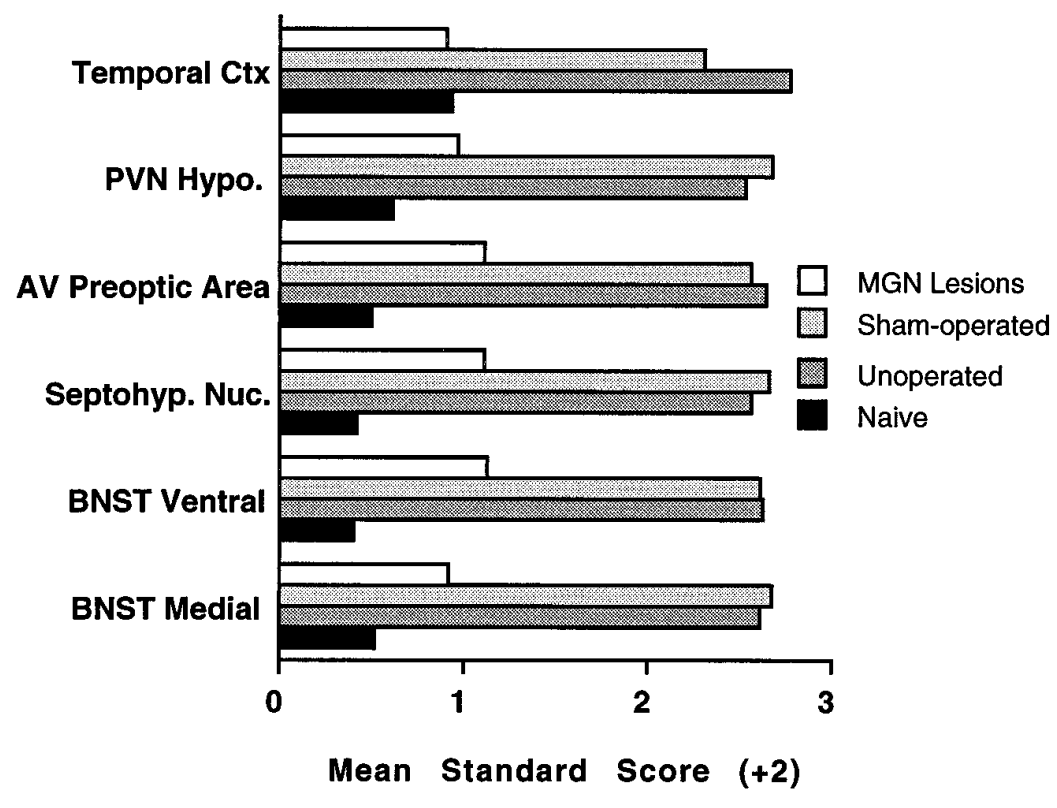

\section{Brain regions where MGN lesions reduced c-fos mRNA induction to audiogenic stress}

Figure 8. Mean standard $(z)$ scores $(+2)$ computed from the transformed integrated densitometric values in regions for which complete medial geniculate nuclei lesions (MGN Lesions) abolished c-fos mRNA induction in response to $105 \mathrm{~dB}$ white noise, compared with unoperated and sham-operated rats. SD in all instances is 1.0. BNST, Bed nucleus of the stria terminalis; Septohyp. Nuc., septohypothalamic nucleus; $A V$, anteroventral; PVN Hypo., paraventricular nucleus of the hypothalamus; $C t x$, cortex.
Figure 9. Mean standard (z) scores (+2) computed from the transformed integrated densitometric values in regions for which complete medial geniculate nuclei lesions (MGN Lesions) produced intermediate c-fos mRNA induction compared with the unoperated and sham-operated rats in response to $105 \mathrm{~dB}$ white noise. SD in all instances is 1.0. Nuc. Acc., Nucleus accumbens; Dor. Endopir. Nuc., dorsal endopiriform nucleus; DM Hypo. Nuc., dorsomedial hypothalamic nucleus; Lat., lateral; Supramam. Nuc., supramammillary nucleus. complete medial geniculate-lesioned rats. Activation of these regions was previously found to be associated more intimately with exposure of rats to the experimental context (Campeau and Watson, 1997). The results of the present study thus suggest that medial geniculate lesions do not alter to a great extent the regional activity in response to exposure to the experimental context, and they further suggest that these regions are not part of a necessary HPA activational circuit recruited by audiogenic stress.

c-fos mRNA induction in several auditory nuclei (cochlear nuclei, superior olivary complex, nuclei of the lateral lemniscus, inferior colliculus) below the level of the medial geniculate nuclei was found to be similar between the lesioned and control rats. Our previous study indicated that high c-fos mRNA induction was obtained in these nuclei in response to loud (105 dB, A scale) noise (Campeau and Watson, 1997). These results therefore suggest that activity in the auditory system below the level of the medial geniculate nuclei is not sufficient to mediate activation of the HPA axis. Furthermore, blockade of loud noise-induced HPA activation by medial geniculate lesions cannot be explained 


\section{Brain regions where MGN lesions had no effect on c-fos mRNA induction to audiogenic stress}

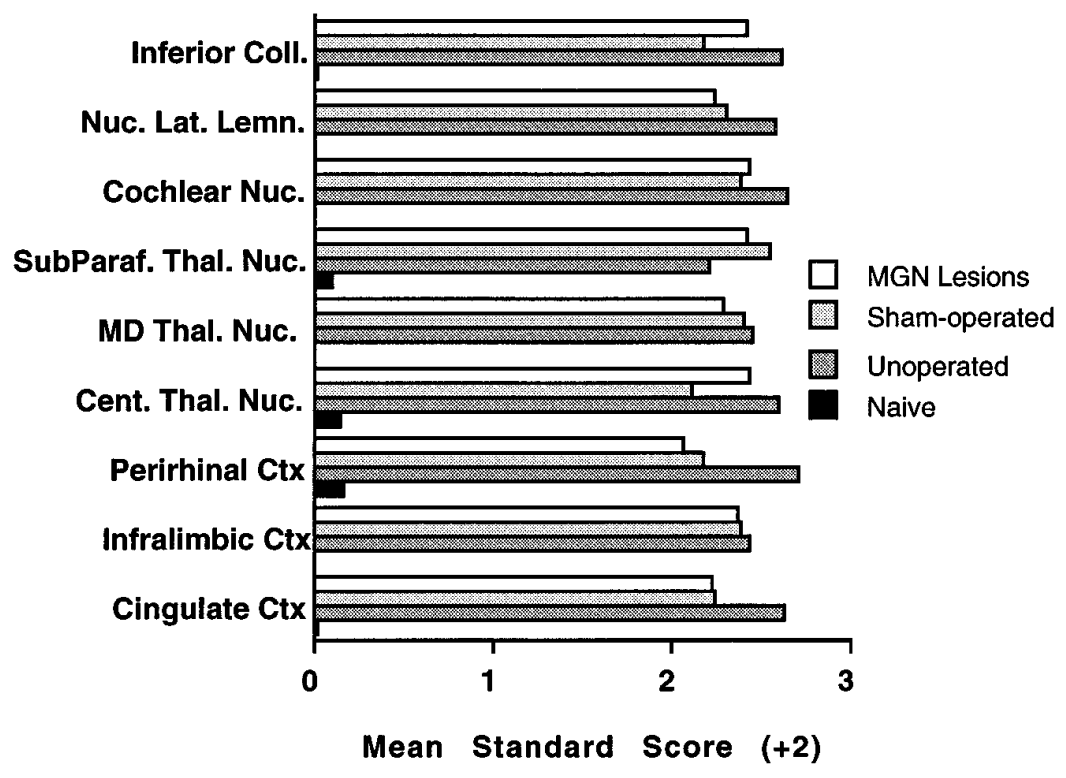

Figure 10. Mean standard $(z)$ scores $(+2)$ computed from the transformed integrated densitometric values in some regions for which all groups exposed to $105 \mathrm{~dB}$ white noise displayed reliable and similar c-fos mRNA induction. SD in all instances is 1.0. Ctx, Cortex; Cent. Thal. Nuc., central thalamic nuclei; $M D$ Thal. Nuc., mediodorsal nucleus of the thalamus; SubParaf. Thal. Nuc., subparafascicular nucleus of the thalamus; Nuc. Lat. Lemn., nuclei of the lateral lemniscus; Coll., colliculus. simply by the fact that lesioned rats have severe hearing impairments, because animals sustaining similar lesions display several acoustically driven behaviors (Kryter and Ades, 1943; Oesterreich et al., 1971; Campeau and Davis, 1995).

On the other hand, c-fos mRNA induction in many of the regions that were specifically responsive to audiogenic stress in our previous study (Campeau and Watson, 1997) failed to show significant c-fos mRNA induction in the complete medial geniculate-lesioned rats, compared with the unoperated and sham-operated rats. These regions included the anterior bed nucleus of the stria terminalis (medial and ventral nuclei), the septohypothalamic nucleus, the anteroventral preoptic area, and the paraventricular nucleus of the hypothalamus. c-fos mRNA induction was prevented in several additional regions of the complete medial geniculate-lesioned rats, but this reduction did not reach statistical significance compared with the unoperated and sham-operated rats, perhaps because of the small number of lesioned animals available for analysis. These regions included the claustrum, the occipital cortex, the dorsal part of the caudate nucleus, the ventral lateral septum, the medial nucleus of the amygdala, the ventral dentate gyrus, the lateral hypothalamic nucleus, the lateroventral central gray, the locus coeruleus, and the median raphe. Several of these regions were also previously observed to be specifically responsive to loud noise (Campeau and Watson, 1997). Thus, disruption of auditory inputs to the forebrain seems to block brain activity specifically associated with audiogenic stress-responsive forebrain structures.

The physiological and anatomical/functional results obtained after complete medial geniculate nuclei lesions suggest a few putative pathways involved in activation of the HPA axis with respect to the known anatomy of medial geniculate nuclei efferents. In rats, the medial geniculate nuclei give rise to two main efferent projections: the auditory areas of the temporal cortex and the lateral nucleus of the amygdala/amygdalostriatal transition area (LeDoux et al., 1985, 1990). Neither of these structures show loud noise-specific c-fos mRNA induction nor do they provide direct efferents to medial parvocellular PVN neurons; however, through additional intra-amygdaloid connections (Stefanacci et al., 1992; Pitkanen et al., 1995), information relayed by the lateral nucleus of the amygdala is known to reach several other amygdaloid subnuclei, which have demonstrated connections to extraamygdaloid areas that show audiogenic stress-responsive c-fos mRNA induction. These include projections from several amygdaloid nuclei to the preoptic area, ventral and medial bed nucleus of the stria terminalis, and septohypothalamic nucleus/ventral lateral septum (Krettek and Price, 1978; Swanson and Cowan, 1979; Weller and Smith, 1982; McDonald, 1987). In turn, several areas among these have demonstrated projections to mpPVN hypothalamic neurons (Sawchenko and Swanson, 1983; Simerly and Swanson, 1988; Cullinan et al., 1993; Moga and Saper, 1994; Cullinan et al., 1996). On the basis of these functional and anatomical data, putative HPA activational circuits in response to audiogenic stress are depicted in Figure 11.

Most of the c-fos mRNA induction results in response to audiogenic stress are consistent with the putative HPA activational circuits discussed above, with the exception of the amygdala. Indeed, c-fos mRNA induction in most amygdaloid nuclei is not consistently reliable (Campeau and Watson, 1997; present study); however, additional results from our laboratory suggest that the lateral nucleus of the amygdala is necessary for corticosterone release in response to audiogenic stress (our unpublished observations). It is thus possible that c-fos mRNA induction does not offer a good index of functional activation, at least in the lateral nucleus of the amygdala, under our experimental conditions. An alternative pathway might involve projections from the auditory thalamus to the temporal/perirhinal cortex region, and from there to the subiculum, which has known projections to the bed nucleus of the stria terminalis and has been shown to play a role in stress (Herman et al., 1992, 1995; Cullinan et al., 1993). As is the case for the amygdala, the subiculum shows low levels of c-fos mRNA induction, similar to other regions of the hippocampal formation, in response to audiogenic stress. Clearly, addi- 


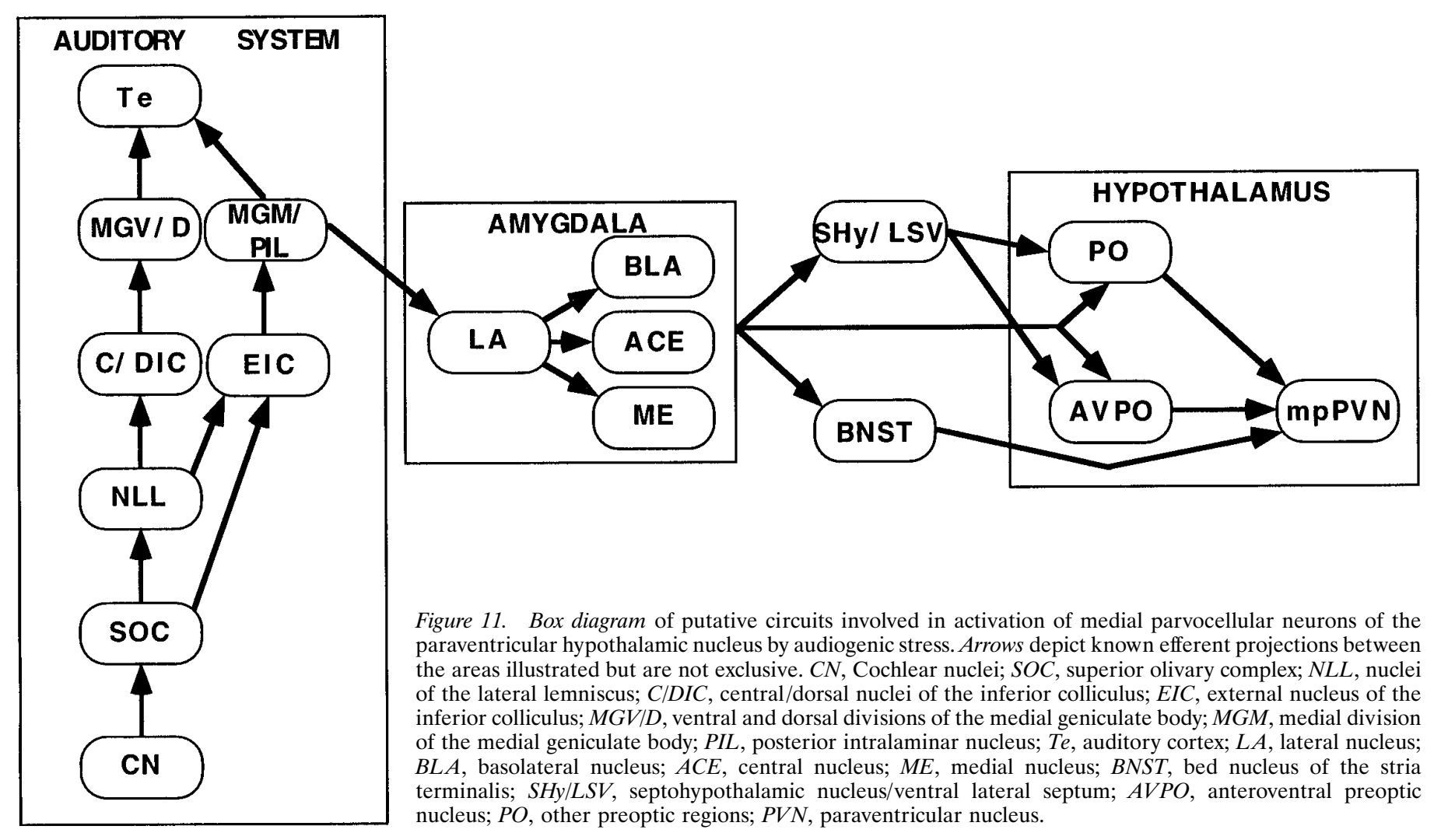

tional lesion studies combined with c-fos mRNA induction measurements are necessary to determine more precisely the role of these structures in HPA activation by audiogenic stress. Without the additional information provided by the disruption of a particular region displaying c-fos mRNA induction in response to a particular stimulus, it might be difficult to ascribe an exact function to such region given that c-fos induction alone cannot discern between direct or indirect effects of a treatment.

In conclusion, the present data indicate that the auditory thalamus is part of the sensory afferent limb of a circuit necessary for activation of the HPA axis by audiogenic stress, but not by restraint or ether stress, presumably through medial geniculate efferents to the forebrain. Combined with the results of previous studies indicating the necessity of different CNS pathways for activation of the HPA axis with different types of visceral stressors (immune and hyperosmotic challenges) (for review, see Sawchenko et al., 1996), the available evidence suggests the existence of several different functional activational pathways to mpPVN neurons recruited by different types of stressful events. Thus, in addition to the documented functional activational pathway from medullary catecholamine cell groups to mpPVN neurons, the present study strongly suggests the existence of forebrain activational pathways to the $\mathrm{mpPVN}$, which remain to be clearly delineated.

\section{REFERENCES}

Aitkin L (1990) The auditory cortex: structural and functional bases of auditory perception. London: Chapman and Hall.

Akil H, Morano M (1996) The biology of stress: from periphery to brain. In: Biology of schizophrenia and affective disease (Watson S, ed), pp 15-48. Washington, DC: American Psychiatric Press.

Antoni FA (1986) Hypothalamic control of adrenocorticotropin secretion: advances since the discovery of 41-residue corticotropin-releasing factor. Endocr Rev 7:351-378.
Armario A, Castellanos J, Balasch J (1984) Adaptation of anterior pituitary hormones to chronic noise stress in male rats. Behav Neural Biol 41:71-76.

Arnold F, De Lucas Bueno M, Shiers H, Hancock D, Evan G, Herbert J (1992) Expression of c-fos in regions of the basal limbic forebrain following intracerebroventricular corticotropin-releasing factor in unstressed and stressed male rats. Neuroscience 51:377-390.

Beck CHM, Fibiger HC (1995) Conditioned fear-induced changes in behavior and in the expression of the immediate early gene c-fos: with and without diazepam pretreatment. J Neurosci 15:709-720.

Bonaz B, Tache Y (1994) Induction of Fos immunoreactivity in the rat brain after cold-restraint induced gastric lesions and fecal excretion. Brain Res 652:56-64.

Borrell J, Torrellas A, Guaza C, Borrell S (1980) Sound stimulation and its effects on the pituitary-adrenocortical function and brain catecholamines in rats. Neuroendocrinology 31:53-59.

Britton KT, Segal DS, Kuczenski R, Hauger R (1992) Dissociation between in vivo hippocampal norepinephrine response and behavioral/ neuroendocrine responses to noise stress in rats. Brain Res 574:125-130.

Campeau S, Davis M (1995) Involvement of subcortical and cortical afferents to the lateral nucleus of the amygdala in fear conditioning measured with fear-potentiated startle in rats trained concurrently with auditory and visual conditioned stimuli. J Neurosci 15:2312-2327.

Campeau S, Hayward M, Hope B, Rosen J, Nestler E, Davis M (1991) Induction of the c-fos proto-oncogene in the rat amygdala during unconditioned and conditioned fear. Brain Res 565:349-352.

Campeau S, Watson SJ (1997) Neuroendocrine and behavioral responses and brain pattern of c-fos induction associated with audiogenic stress. J Neuroendocrinol, in press.

Collu R, Jequier JC (1976) Pituitary response to auditory stress: effects of treatment with $\alpha$-methyl-p-tyrosine. Usefulness of a factorial mixed design for statistical analysis. Can J Physiol Pharmacol 54:596-602.

Cullinan WE, Herman JP, Watson SJ (1993) Ventral subicular interaction with the hypothalamic paraventricular nucleus: evidence for a relay in the bed nucleus of the stria terminalis. J Comp Neurol 332:1-20.

Cullinan WE, Herman JP, Battaglia DF, Akil H, Watson SJ (1995) Pattern and time course of immediate early gene expression in rat brain following acute stress. Neuroscience 64:477-505. 
Cullinan W, Helmreich D, Watson S (1996) Fos expression in forebrain afferents to the hypothalamic paraventricular nucleus following swim stress. J Comp Neurol 368:88-99.

Cunningham EJ, Bohn M, Sawchenko P (1990) The organization of adrenergic projections to the paraventricular and supraoptic nuclei of the hypothalamus in the rat. J Comp Neurol 292:651-667.

Day HEW, Akil H (1996) Differential pattern of c-fos mRNA in rat brain following central and systemic administration of interleukin-1- $\beta$ : implications for mechanism of action. Neuroendocrinology 63:207-218.

Duncan G, Johnson K, Breese G (1993) Topographic patterns of brain activity in response to swim stress: assessment by 2-deoxyglucose uptake and expression of Fos-like immunoreactivity. J Neurosci 13:3932-3943.

Duncan G, Knapp D, Breese G (1996) Neuroanatomical characterization of Fos induction in rat behavioral models of anxiety. Brain Res 713:79-91.

Feldman S, Conforti N, Chowers I (1972) Neural pathways mediating adrenocortical responses to photic and acoustic stimuli. Neuroendocrinology 10:316-323.

Fendler K, Karmos G, Telegdy G (1961) The effect of hippocampal lesion on pituitary-adrenal function. Acta Physiol 20:293-297.

Helfert RH, Snead CR, Altschuler RA (1991) The ascending auditory pathways. In: Neurobiology of hearing: the central auditory system (Altschuler RA, Bobbin RP, Clopton BM, Hoffman DW, eds), pp 1-25. New York: Raven.

Henkin RI, Knigge KM (1963) Effect of sound on the hypothalamicpituitary-adrenal axis. Am J Physiol 204:910-914.

Herman JP, Cullinan WE (1997) Neurocircuitry of stress: central control of the hypothalamo-pituitary-adrenocortical axis. Trends Neurosci 20:78-84.

Herman JP, Cullinan WE, Young EA, Akil H, Watson SJ (1992) Selective forebrain fibertract lesions implicate ventral hippocampal structures in tonic regulation of paraventricular nucleus CRH and AVP mRNA expression. Brain Res 592:228-238.

Herman JP, Cullinan WE, Morano MI, Akil H, Watson SJ (1995) Contribution of the ventral subiculum to inhibitory regulation of the hypothalamo-pituitary-adrenocortical axis. J Neuroendocrinol 7:475-482.

Herman JP, Prewitt CM-F, Cullinan WE (1996) Neuronal circuit regulation of the hypothalamo-pituitary-adrenocortical stress axis. Crit Rev Neurobiol 10:371-394.

Irwin MR, Segal DS, Hauger RL, Smith TL (1989) Individual behavioral and neuroendocrine differences in responsiveness to audiogenic stress. Pharmacol Biochem Behav 32:913-917.

Knigge KM (1961) Adrenocortical response to stress in rats with lesions of the hippocampus and amygdala. Proc Soc Exp Biol Med 108:67-69.

Krettek JE, Price JL (1978) Amygdaloid projections to subcortical structures within the basal forebrain and brainstem in the rat and cat J Comp Neurol 178:225-254.

Kryter KD, Ades HW (1943) Studies on the function of the higher acoustic nervous centers in the cat. Am J Psychol 56:501-536.

LeDoux JE, Sakaguchi A, Reis DJ (1984) Subcortical efferent projections of the medial geniculate nucleus mediate emotional responses conditioned to acoustic stimuli. J Neurosci 4:683-698.

LeDoux JE, Ruggiero DA, Reis DJ (1985) Projections to the subcortical forebrain from anatomically defined regions of the medial geniculate body in the rat. J Comp Neurol 242:182-213.

LeDoux JE, Ruggiero DA, Forest R, Stornetta R, Reis DJ (1987) Topographic organization of convergent projections to the thalamus from the inferior colliculus and spinal cord in the rat. J Comp Neurol 264:123-146.

LeDoux JE, Farb C, Ruggiero DA (1990) Topographic organization of neurons in the acoustic thalamus that project to the amygdala. J Neurosci 10:1043-1054.

LeDoux JE, Farb CR, Romanski LM (1991) Overlapping projections to the amygdala and striatum from auditory processing areas of the thalamus and cortex. Neurosci Lett 134:139-144.

Li H-Y, Ericsson A, Sawchenko P (1996) Distinct mechanisms underlie activation of hypothalamic neurosecretory neurons and their medullary catecholaminergic afferents in categorically different stress paradigms. Proc Natl Acad Sci USA 93:2359-2364.

McDonald AJ (1987) Somatostatinergic projections from the amygdala to the bed nucleus of the stria terminalis and medial preoptichypothalamic region. Neurosci Lett 75:271-277.

Melia KR, Ryabinin AE, Schroeder R, Bloom FE, Wilson MC (1994) Induction and habituation of immediate early gene expression in rat brain by acute and repeated restraint stress. J Neurosci 14:5929-5938.

Moga M, Saper C (1994) Neuropeptide-immunoreactive neurons projecting to the paraventricular hypothalamic nucleus in the rat. J Comp Neurol 346:137-150.

Oesterreich RE, Strominger NL, Neff WD (1971) Neural structures mediating differential sound intensity discrimination in the cat. Brain Res 27:251-270.

Paxinos G, Watson C (1986) The rat brain in stereotaxic coordinates, 2nd edition. Sydney: Academic.

Pezzone M, Lee W-S, Hoffman G, Rabin B (1992) Induction of c-Fos immunoreactivity in the rat forebrain by conditioned and unconditioned aversive stimuli. Brain Res 597:41-50.

Pezzone M, Lee W-S, Hoffman G, Pezzone K, Rabin B (1993) Activation of brainstem catecholaminergic neurons by conditioned and unconditioned aversive stimuli as revealed by c-Fos immunoreactivity. Brain Res 608:310-318.

Pitkanen A, Stefanacci L, Farb CR, Go GG, LeDoux JE, Amaral DG (1995) Intrinsic connections of the rat amygdaloid complex: projections originating in the lateral nucleus. J Comp Neurol 356:288-310.

Sawchenko PE (1991) The final common path: issues concerning the organization of central mechanisms controlling corticotropin secretion. In: Stress neurobiology and neuroendocrinology (Brown M, Koob G, Rivier C, eds), pp 55-71. New York: Marcel Dekker.

Sawchenko PE, Swanson LW (1982) The organization of noradrenergic pathways from the brainstem to the paraventricular and supraoptic nuclei in the rat. Brain Res Rev 4:275-325.

Sawchenko PE, Swanson LW (1983) The organization of the forebrain afferents to the paraventricular and supraoptic nuclei. J Comp Neurol 218:121-144.

Sawchenko PE, Brown ER, Chan RKW, Ericsson A, Li H-Y, Roland BL, Kovacs KJ (1996) The paraventricular nucleus of the hypothalamus and the functional neuroanatomy of visceromotor responses to stress. Prog Brain Res 107:201-222.

Schreiber SS, Tocco G, Shors TJ, Thompson RF (1991) Activation of immediate early genes after acute stress. NeuroReport 2:17-20.

Segal DS, Kuczenski R, Swick D (1989) Audiogenic stress response: behavioral characteristics and underlying monoamine mechanisms. J Neural Transm 75:31-50.

Senba E, Matsunaga K, Tohyama M, Noguchi K (1993) Stress-induced c-fos expression in the rat brain: activation mechanism of sympathetic pathway. Brain Res Bull 31:329-344.

Sharp F, Sagar S, Hicks K, Lowenstein D, Hisanga K (1991) c-fos mRNA, Fos and Fos-related antigen induction by hypertonic saline and stress. J Neurosci 11:2321-2331.

Simerly RB, Swanson LW (1988) Projections of the medial preoptic nucleus: a Phaseolus vulgaris leucoagglutinin anterograde tract-tracing study in the rat. J Comp Neurol 270:209-242.

Smith MA, Banerjee S, Gold PW, Glowa J (1992) Induction of c-fos mRNA in rat brain by conditioned and unconditioned stressors. Brain Res 578:135-141.

Stefanacci L, Farb CR, Pitkanen A, Go G, LeDoux JE, Amaral DG (1992) Projections from the lateral nucleus to the basal nucleus of the amygdala: a light and electron microscopic PHA-L study in the rat. J Comp Neurol 323:586-601.

Swanson LW, Cowan WM (1979) The connections of the septal region in the rat. J Comp Neurol 186:621-656.

Swanson LW, Sawchenko PE, Lind RW, Rho J-H (1988) The CRH motoneuron: differential peptide regulation in neurons with possible synaptic, paracrine and endocrine outputs. Ann NY Acad Sci USA 512:12-23.

Vazquez D, Akil H (1993) Pituitary-adrenal response to ether vapor in the weanling animal: characterization of the inhibitory effect of glucocorticoids on adrenocorticotropin secretion. Pediatr Res 34:646-653.

Weller KL, Smith DA (1982) Afferent connections to the bed nucleus of the stria terminalis. Brain Res 232:255-270.

Whitnall MH (1993) Regulation of the hypothalamic corticotropinreleasing hormone neurosecretory system. Prog Neurobiol 40:573-629. 